\title{
Evolution of malignant plasmacytoma cell lines from K14E7 Fancd 2-/- mouse long-term bone marrow cultures
}

\author{
Xichen Zhang ${ }^{1}$, Wen Hou ${ }^{1}$, Michael W. Epperly ${ }^{1}$, Lora Rigatti ${ }^{2}$, Hong Wang ${ }^{1}$, Darcy \\ Franicola $^{1}$, Aranee Sivanathan ${ }^{1}$, Joel S. Greenberger ${ }^{1}$ \\ ${ }^{1}$ Department of Radiation Oncology, University of Pittsburgh Cancer Institute, Pittsburgh, 15232 PA, USA \\ ${ }^{2}$ Division of Laboratory Animal Resources, University of Pittsburgh, Pittsburgh, 15260 PA, USA \\ Correspondence to: Joel S. Greenberger, email: greenbergerjs@upmc.edu
}

Keywords: E7, HPV oncogene, human papillomavirus, Fanconi anemia, Fancd2/- mice

Received: April 29, 2016

Accepted: September 02, 2016

Published: September 15, 2016

\section{ABSTRACT}

We tested the effect of expression of the Human Papilloma Virus (HPV E7) oncogene on hematopoiesis in long-term bone marrow cultures (LTBMCs) derived from K14E7 (FVB) Fancd2-/- (129/Sv), K14E7 Fancd2 ${ }^{+/+}$, Fancd2 ${ }^{-/}$, and control (FVB $X$ 129/Sv) FI mice. K14E7 Fancd2 ${ }^{-/-}$and Fancd2 ${ }^{-/-}$LTBMCs showed decreased duration of production of total nonadherent hematopoietic cells and progenitors forming day 7 and day 14 multilineage CFU-GEMM colonies in secondary cultures ( 7 wks and 8 wks respectively) compared to cultures from K14E7 Fancd2 ${ }^{+/+}(17 \mathrm{wks})$ or control mice (18 wks) $p<0.0001$. Marrow stromal cell lines derived from both K14E7 Fancd2-/and Fancd $2^{-/-}$cultures were radiosensitive, as were IL-3 dependent hematopoietic progenitor cell lines derived from K14E7 Fancd2-/- cultures. In contrast, Fancd2-/mouse hematopoietic progenitor cell lines and fresh marrow were radioresistant. K14E7 Fancd 2-/- mouse freshly explanted bone marrow expressed no detectable K14 or E7; however, LTBMCs produced K14 positive factor-independent (FI) clonal malignant plasmacytoma forming cell lines in which E7 was detected in the nucleus with p53 and Rb. Transfection of an E6/E7 plasmid into Fancd2-/-, but not control Fancd $2^{+/+}$IL-3 dependent hematopoietic progenitor cell lines, increased cloning efficiency, cell growth, and induced malignant cell lines. Therefore, the altered radiobiology of hematopoietic progenitor cells and malignant transformation in vitro by K14E7 expression in cells of the Fancd2-/- genotype suggests a potential role of HPV in hematopoietic malignancies in FA patients.

\section{INTRODUCTION}

Fanconi Anemia (FA) patients display a variety of inherited and acquired phenotypes [1], which are dependent upon mutation or deletion of one or more of the 18 gene products in the FA pathway [2-3]. Proteins in the FA complex form a scaffold onto which bind other proteins involved in the process of DNA repair and lead to monoubiquination of Fancd2, which when bound to FancI faciliates repair of DNA double strand breaks [4]. The FA pathway proteins are involved in other molecular mechanisms of disease including genome instability [4], tumorigenesis [5-6], hematopoietic failure [7], and radiosensitivity [8-10].

Human papillomavirus (HPV) is involved in genesis of squamous cell cancer of the head and neck, esophagus, and cervix [11-15]; however, its possible role in hematologic malignancies [16] has not been established. Fanconi Anemia (FA) patients have an increased frequency of squamous cell head and neck cancers [17-20]. The hypotheses that FA patients are more susceptible to malignant transformation of squamous cells by HPV, and that evolution of such cancers might relate to the intrinsic cellular radiosensitivity and FA pathway protein alterations, are subjects of current investigation $[6,17$, 21-23]. Some HPV positive head and neck squamous cell cancers are radiosensitive [17]. HPV can alter DNA double strand break repair by homologous recombination [23], (a pathway which is already defective in FA patients [2-3]). HPV enhances TGF- $\beta$ signaling [24], which may be deleterious in FA patients, who have a hyperactive response to TGF- $\beta$ [25]. 
Recently, Fanconi Anemia (FA) Fancd2 ${ }^{-/-}$(129/ Sv) mice with cytokeratin 14 (K14) promoter controlled production of E7 onco-protein of HPV derived from genetic cross with K14E7 mice (FVB/n) were shown to be susceptible to both chemical carcinogen induced oral squamous cell tumors, and estrogen pellet induced cervix cancers [26]. The data suggested that in the presence of a chemical carcinogen or estrogen stimulation, the E7 oncoprotein interacted with an element(s) of the defective FA pathway in Fancd $2^{--}$mice and could induce malignant transformation of squamous epithelium in tissues that naturally express cytokeratin 14 .

In the present studies, we determined whether culture of K14E7 Fancd2 ${ }^{-/}$mouse marrow in LTBMCs [28] facilitated expression of K14 driven E7, and whether there was altered hematopoiesis. While K14E7 Fancd $2^{-/-}$mouse LTBMCs retained some Fancd $2^{-/}$phenotypes including: suppressed duration of hematopoiesis and radiosensitivity of marrow stromal cell lines, we discovered that culturederived hematopoietic cell lines, as well as fresh marrow hematopoietic progenitors were also radiosensitive, a distinct difference from Fancd $2^{-/-}$marrow. Furthermore, cytokeratin 14 and E7 were expressed in cultured K14E7 Fancd $2^{-/-}$marrow and nonadherent cells subcultured in Interleukin-3 (IL-3) generated factor-independent (FI) malignant plasmacytoma cell lines.

\section{RESULTS}

\section{Reduced longevity of hematopoiesis in K14E7 fancd $2^{-/-}$mouse LTBMCs}

Long-term bone marrow cultures were established from the tibia and femur marrow of four mice ( 8 cultures) of each genotype: K14E7Fancd2 ${ }^{-/-}$, K14E7Fancd2 $2^{+/+}$ $(\mathrm{FVB} / \mathrm{N})$, Fancd $2^{+/+}(129 / \mathrm{Sv})$, and control $(129 / \mathrm{Sv}$ $\mathrm{X}$ FVB) $\mathrm{F}_{1}$ mice [26], and maintained according to published methods [9]. As shown in Figure 1A, adherent cell layers reached confluence within six weeks for all genotype groups. There was a slight delay (not statistically significant) (Supplementary Table S1) in the time to confluence of adherent cell layers in Fancd $2^{-/}$mouse long-term bone marrow cultures. The cobblestone island numbers on the adherent layer of each flask (indicative of hematopoietic stem cell interaction with stromal cells of the hematopoietic microenvironment, and the robustness of hematopoiesis) are shown in Figure 1B (Supplementary Table S2). Marrow cultures from Fancd $2^{+/+}$and K14E7Fancd2 $2^{+/+}$mice showed greater numbers of cobblestone islands during weeks 1 through 14 compared to those detected in either K14E7Fancd $2^{-/}$ or Fancd $2^{-/}$groups (Figure 1B). Cumulative cobblestone island production (Figure 1C) also showed greater numbers in cultures from the Fancd $2^{+/+}$genotypes. These results showing decreased production of hematopoietic cells in LTBMCs form K14E7 Fancd2 ${ }^{-/-}$mice confirm and extend those results of decreased hematopoietic cell production shown with both Fancd $2^{-/-}$(C57BL/6J) [9] and Fancd2 $2^{-/}(129 / \mathrm{Sv})$ mouse LTBMCs [10].

The weekly production of non-adherent cells (Figure 1D) and cumulative cell numbers per flask (Figure 1E) were increased in cultures from Fancd $2^{+/+}$ and K14E7 Fancd2 ${ }^{+/+}$mice (Supplementary Table S3). Results for cumulative production (Figure 1E) were also higher in cultures from Fancd2 $2^{+/+}$or K14E7Fancd2 $2^{+/+}$ mice. In contrast, K14E7Fancd $2^{-/-}$and Fancd $2^{-/-}$mouse long-term bone marrow cultures showed decreased weekly (Figure 1D) and cumulative (Figure 1E) production of non-adherent cells. These results showing reduced overall culture longevity were similar to those with Fancd $2^{-/-}$ C57BL/6 bone marrow cultures [9]. Therefore, the reduced longevity of hematopoiesis in LTBMCs derived from Fancd $2^{-/}$mice of a different $(129 / \mathrm{Sv})$ genetic background was similar to that of Fancd $2^{-/-}$marrow from C57BL/6 mice [9]. The data also show that addition of the K14E7 genotype did not alter the reduced longevity of hematopoietic cell production in Fancd $2^{-/-}$marrow cultures.

The production of multilineage hematopoietic cells forming colonies in secondary culture (scored as those with greater than 50 cells at day 7 or day 14) were next evaluated. As shown in (Figure 1F, 1G) (Supplementary Table S4), weekly production of day 7 CFU-GEMM colonies, and also those cells forming colonies of greater and equal to 50 cells at 14 days (Figure 1H, 1I) (Supplementary Table S5) (indicative of more primitive hematopoietic cell progenitors) was clearly decreased in both Fancd2 $2^{-/-}(129 / \mathrm{Sv})$ and K14E7 Fancd2 $2^{-/-}$mouse long-term bone marrow cultures. The production of both day 7 and day 14 colony forming cells was decreased with respect to both weekly and cumulative production by $\mathrm{K} 14 \mathrm{E} 7 \mathrm{Fancd} 2^{-/-}$mouse marrow cultures.

Long-term cultures from K14E7Fancd2 $2^{+/+}$mice showed an earlier plateau with respect to cumulative cell production of day 7 (Figure 1G) and day 14 (Figure 1I) CFU-GEMM compared to the continuous production of hematopoietic cell colony forming units in Fancd $2^{+/+}$ $(129 / \mathrm{Sv})$ marrow cultures. The effects of the K14E7 genotype on Fancd $2^{+/+}$long-term marrow culture production of day 14 colony forming cells, weekly (Figure 1H) and cumulative (Figure 1G) were as pronounced as that observed with day 7 colony forming cells. As shown in Figure $1 \mathrm{H}$ ), there was a plateau in production of day 14 hematopoietic colony forming cells at around week 6 in K14E7Fancd $2^{+/+}$cultures, while numbers continued to increase weekly and in cumulative fashion for Fancd $2^{+/+}$ marrow derived colony forming cells. These data establish that expression of K14E7 in Fancd $2^{-/-}$marrow did not alter the suppressed duration of hematopoiesis observed in Fancd $2^{-/-}$mouse long-term bone marrow cultures (Supplementary Tables S1-S5). 
A

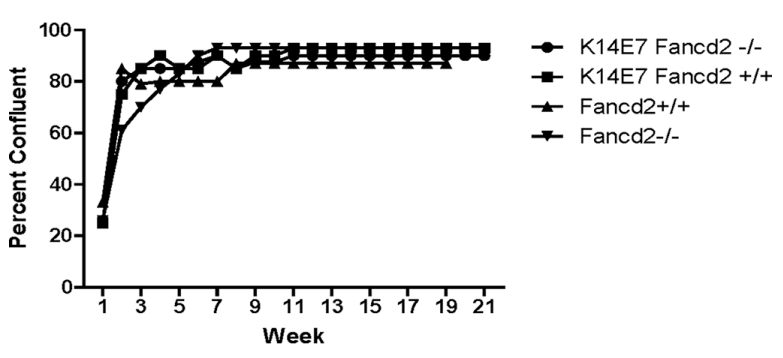

B

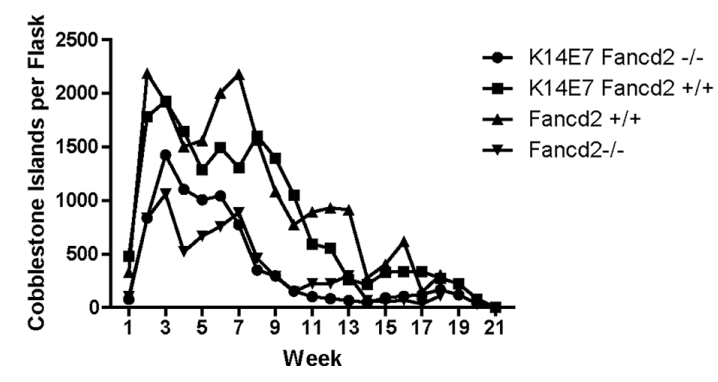

E

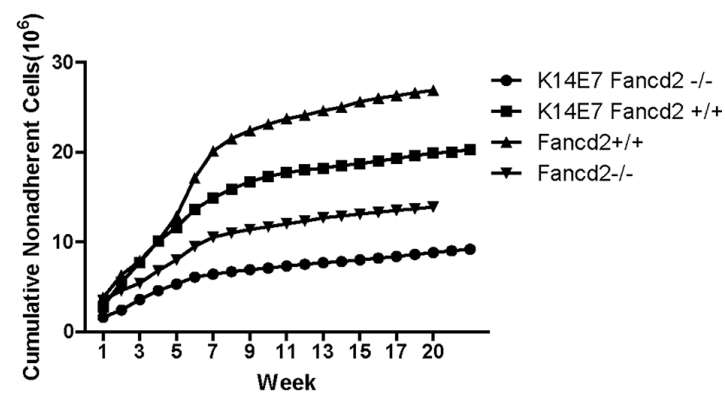

$\mathbf{F}$

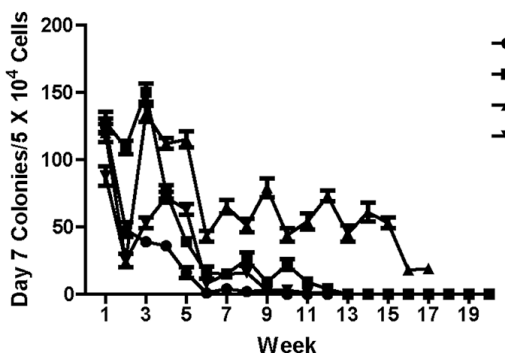

C

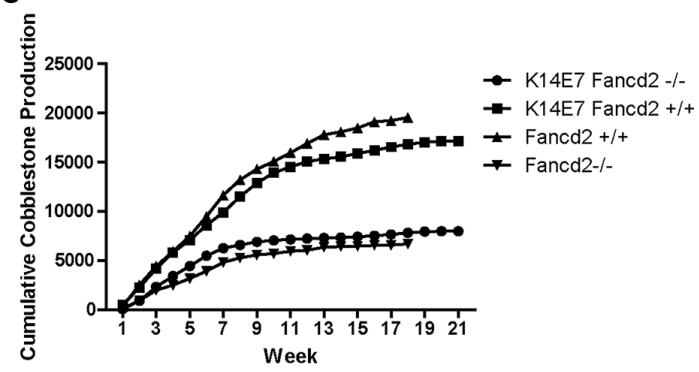

D

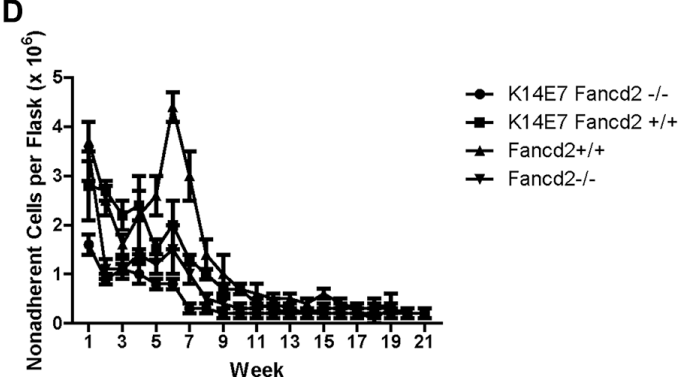

G

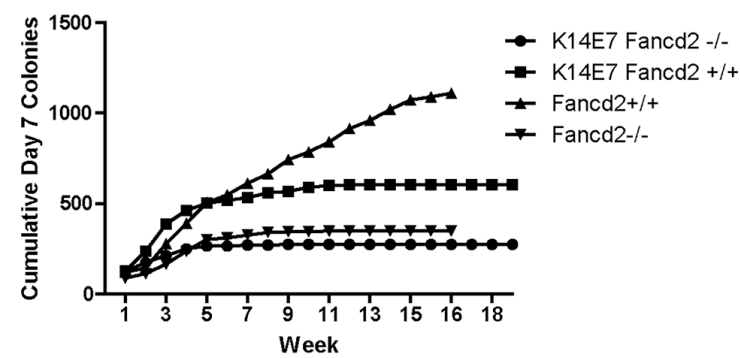

H

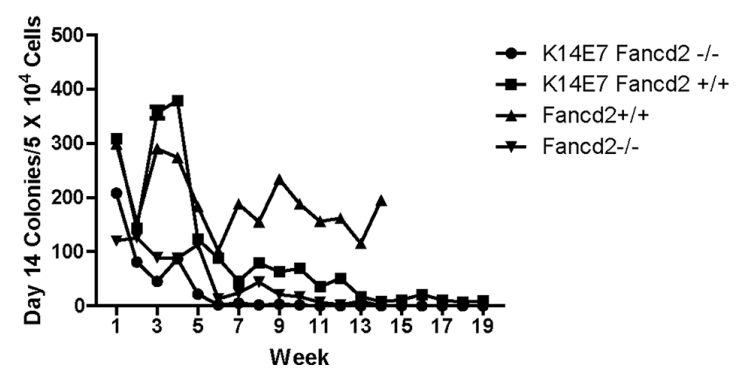

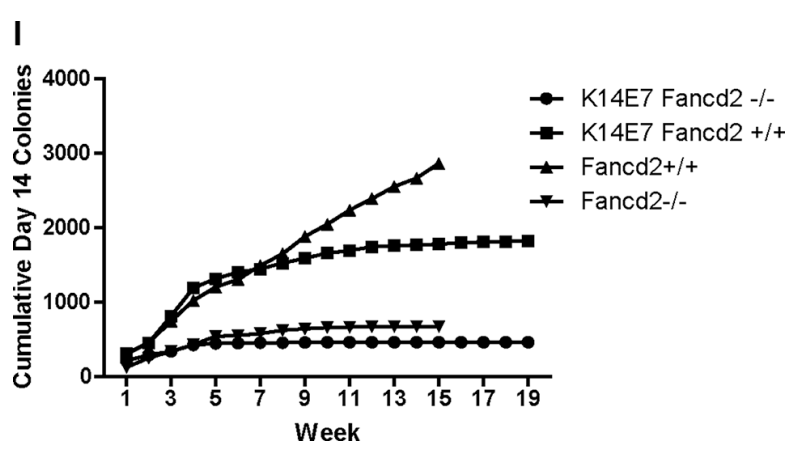

Figure 1: LTBMCs from K14E7Fancd2 ${ }^{--}$mice show reduced longevity of hematopoiesis. (A) adherent area confluent with stromal cells; (B) weekly count of cobblestone islands; (C) cumulative cobblestone islands; (D) weekly count of NA cells; (E) cumulative NA cells; (F) weekly scoring of D7 CFU-GEMM; (G) cumulative D7 CFU-GEMM; (H) weekly scoring of D14 CFU-GEMM; and (I) cumulative D14 CFU-GEMM. ( $N=8$ cultures/genotype). 


\section{Long-term marrow cultures derived from oral 4-NQO treated K14E7Fancd2 ${ }^{-/-}$mice demonstrate no alteration in the duration of hematopoiesis}

We next tested whether LTBMCs derived from 4-NQO treated K14E7Fancd2 ${ }^{-/-}$or K14E7Fancd2 $2^{+/+}$ mice showed marrow toxicity or induced malignant transformation that was detectable in LTBMCs. Mice received 4-NQO in drinking water for the timeduration and under protocol conditions for induction of oral cavity cancers as described in the methods and in [26]. The K14E7 Fancd2 ${ }^{-/}$, but not K14E7 Fancd $2^{+/+}$mice in these experiments did develop oral cavity squamous cell tumors (Figure 4A-4B). Marrow from 4-NQO treated tumor-bearing K14E7 Fancd2 $2^{-/-}$or control 4-NQO treated K14E7 Fancd2 ${ }^{+/+}$ mice was placed into LTBMC. As shown in Figure 2, there was no detectable effect of 4-NQO treatment on the genotype dependent time to reach a plateau in the confluence of the adherent layer of long-term marrow cultures (Figure 2A). K14E7Fancd $2^{-/-}$mouse marrow showed a decrease in weekly production and cumulative production of cobblestone islands (Figure 2B and 2C, respectively) similar to the data with LTBMCs from non 4-NQO treated mice (Figure 1). The results establish that reduced hematopoiesis in LTBMCs from K14E7 Fancd $2^{-/}$mice was independent of previous oral 4-NQO treatment. In explanted marrow from mice that received 4-NQO in the drinking water, the production of non-adherent cells was decreased in K14E7Fancd2 $2^{-1}$ mouse compared to K14E7 Fancd2 $2^{+/+}$mouse marrow cultures measured weekly (Figure 2D) or by calculation of cumulative cell production (Figure 2E).

The production of nonadherent day 7 colony forming cells by 4-NQO treated K14E7 Fancd2 ${ }^{-/-}$ compared to 4-NQO treated control K14E7 Fancd2 $^{+/+}$ mouse bone marrow cultures showed that former had a reduction in weekly (Figure 2F) and cumulative colony forming cell numbers (Figure 2G). Numbers of day 14 colony forming cells measured on a weekly (Figure $2 \mathrm{H}$ ) and cumulative basis (Figure 2I) showed reduced numbers in K14E7 Fancd2 $2^{-/}$cultures. These results establish that marrow from orally 4-NQO treated K14E7 Fancd $2^{-/-}$mice did not reveal overall alteration in in vitro hematopoiesis in LTBMCs nor did it increase or further suppress of the duration of hematopoiesis. There was some reduction in colony forming cells in 4-NQO treated K14E7 Fancd2 ${ }^{-1}$ cultures. There was also an increase in cell numbers in K14E7 Fancd $2^{+/+}$cultures at early weeks. Furthermore, the oral chemical carcinogen 4-NQO treatment did not stimulate detectable morphologic or phenotypic changes in LTBMCs held for 8 weeks after marrow explant.

\section{Radiosensitivity of LTBMC-derived stromal and hematopoietic progenitor cell lines and fresh marrow hematopoietic colony forming cells from K14E7 Fancd2 $^{-/-}$mice}

We established clonal bone marrow stromal and hematopoietic progenitor cell lines from long-term marrow cultures of each mouse genotype. Clonal marrow stromal cell lines derived from K14E7 Fancd2 ${ }^{--}$, as well as Fancd2 ${ }^{-1}$ mouse marrow cultures were radiosensitive (Figure 3A, Table 1). In contrast, clonal IL-3 dependent hematopoietic progenitor cell lines derived from Fancd2 $2^{-/}(129 / \mathrm{Sv})$ LTMBCs (Figure 3B, Table 2), as well as fresh marrow colony forming progenitors (Figure 3C, Table 3) were radioresistant when scored for formation of 50 cell CFUGEMM colonies. The results with Fancd2 $2^{--}(129 / \mathrm{Sv})$ marrow derived cell lines and fresh marrow CFU-GEMM [3] showing radioresistance of hematopoietic cells and radiosensitivity of stromal cells confirm and extend prior results showing the same patterns with hematopoietic compared to marrow stromal cell lines from Fancd2 ${ }^{-/-}(\mathrm{C} 57 \mathrm{BL} / 6)$ mice [9].

In marked contrast, K14E7 Fancd2 ${ }^{--}$LTBMC culture-derived clonal IL-3 dependent cell lines (Figure 3B) and fresh marrow derived CFU-GEMM (Figure 3C) were radiosensitive. Compared to results with Fancd2 $2^{-/-}$ mice, freshly removed marrow and LTBMC-derived IL-3 dependent hematopoietic progenitor cell lines, from K14E7 Fancd $2^{--}$mice showed a clear change in phenotype in that hematopoietic cells, as well as bone marrow stromal cell lines were radiosensitive.

\section{Evolution of clonal malignant plasmacytoma forming cell lines from K14E7 Fancd2 ${ }^{--}$ LTBMCs}

The morphology of 4-NQO induced oral tumors in K14E7 Fancd2 $2^{--}$mice (Figure 4A-4B) was similar to that reported previously [26]. Unexpectedly, K14E7Fancd2 ${ }^{-/}$ LTBMC derived IL-3 dependent non-adherent cells harvested at either week 4 or week 14 (kept as both uncloned lines, and clonal lines expanded from single cell cultures and passaged weekly) produced both adherent and nonadherent cells in IL-3 supplemented secondary cultures (Figure 4C). Weekly passage of nonadherent cells continued to generate persistent adherent and nonadherent hematopoietic cells.

The observation of morphologic changes in K14E7 Fancd $2^{-/-}$marrow cells in IL-3 containing secondary culture suggested either the persistence of two cell populations (both adherent and nonadherent) or that these subcultures contained a novel bilineage mesenchymal/ hematopoietic cell phenotype. To distinguish between these possibilities, clonal cell lines were derived 
A

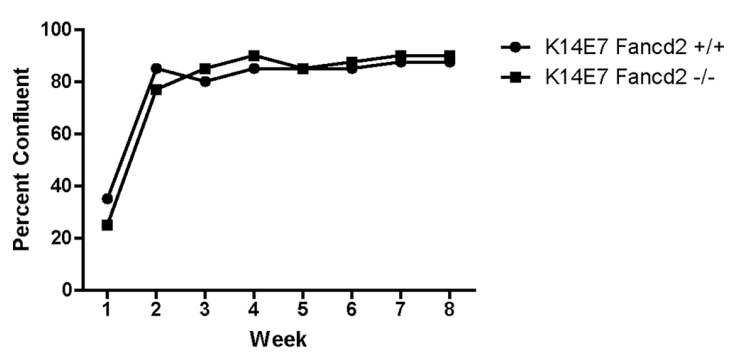

B
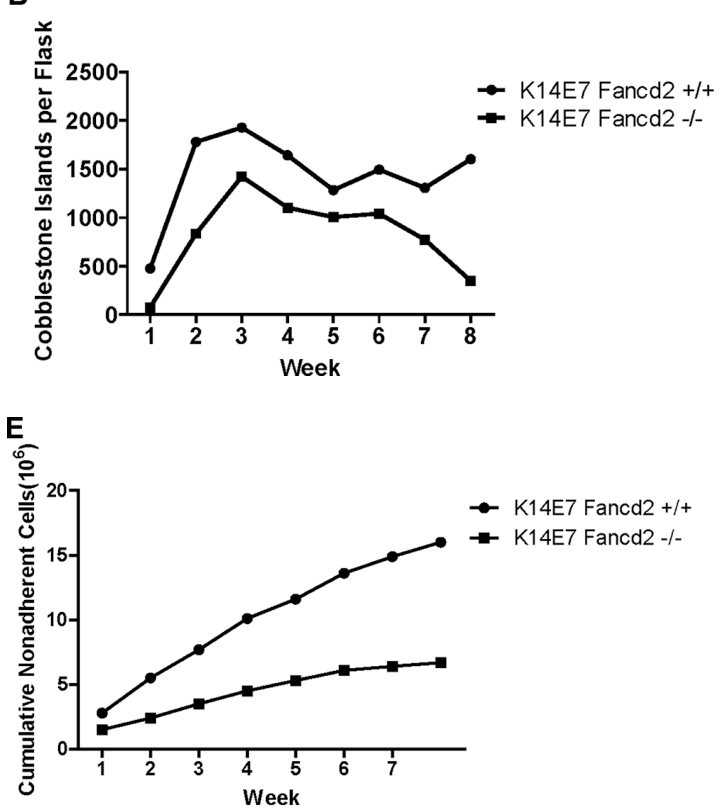

$F$

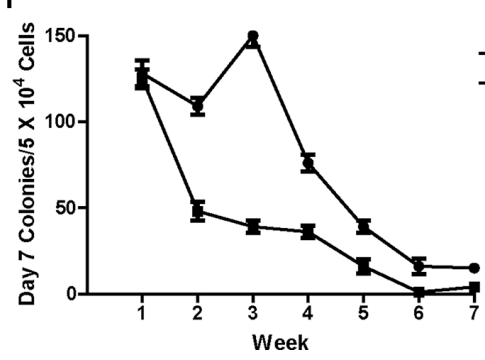

K14E7 Fancd2 +/+

K14E7 Fancd2 - -
C

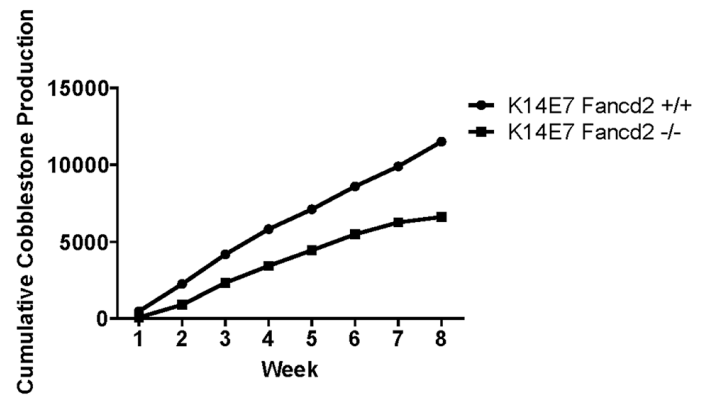

D

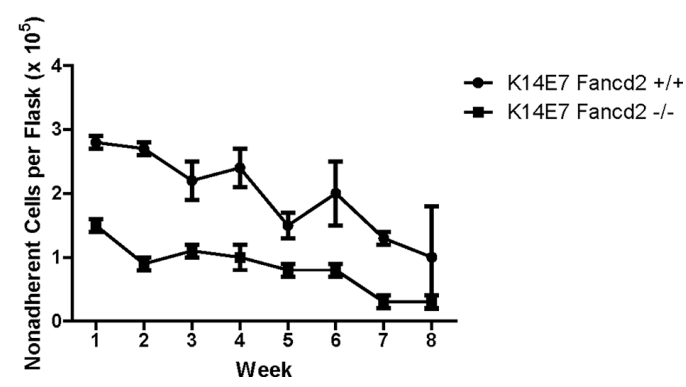

G

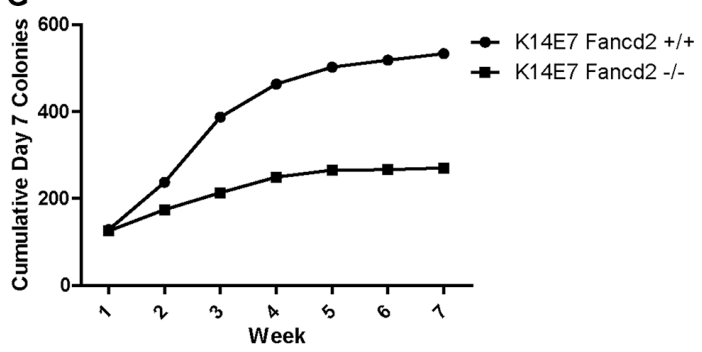

H

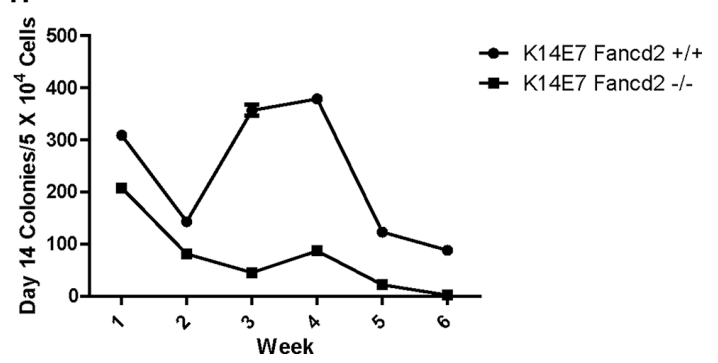

I

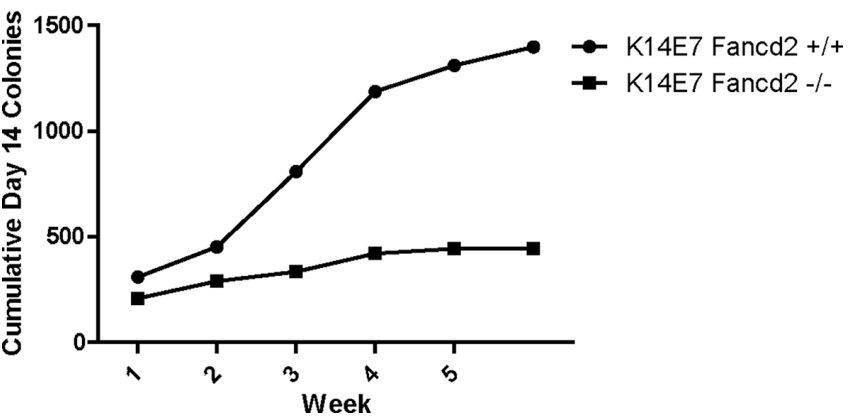

Figure 2: LTBMCs from oral-4NQO treated K14E7Fancd2 ${ }^{-/}$mice show reduced duration of hematopoiesis. Groups of K14E7 Fancd2 ${ }^{+/+}$and K14E7 Fancd2 $2^{-/}$mice received 4NQO in drinking water at $100 \mu \mathrm{M}$ for 10 weeks as published (26), then were placed on regular drinking water for 22 weeks. Marrow cultures were then established as described in the methods. (A) areas of confluent stromal cells; (B) cobblestone islands weekly; (C) cobblestone islands cumulative; (D) weekly NA cells; (E) Cumulative NA cells; (F) weekly D7 CFU-GEMM; (G) cumulative D7 CFU-GEMM; (H) weekly D14 CFU-GEMM; and (I) cumulative D14 CFU-GEMM. 
from IL-3 dependent cell lines from LTBMCs of each mouse genotype. All clonal cell lines derived from K14E7 Fancd $2^{-/-}$marrow cultures showed the same pattern of both adherent and nonadherent cells (Figure 4C). In contrast, IL-3 dependent clonal cell lines derived from all other groups of LTBMCs showed only nonadherent suspension cultured cells. The cloning efficiency of IL-3 dependent cells in subcultures from K14E7 Fancd2 $2^{-/}$ LTBMCs was significantly higher (19/20 single cells) than those obtained from K14E7 Fancd2 ${ }^{+/+}$IL-3 dependent secondary cell cultures (1/50) single cells.

We next tested K14E7 Fancd $2^{-/-}$adherent stromal and the novel IL-3 dependent cell lines for expression of K14 and E7 and compared this data with that from freshly removed organs from the same K14E7 Fancd2 ${ }^{-/-}$, as well as control K14E7 Fancd2 ${ }^{+/+}$, and other control mice. As shown in Figure 5A, the adherent stromal cell lines from both K14E7 Fancd2 ${ }^{+/+}$and K14E7 Fancd2 ${ }^{-/-}$LTBMCs were positive for both K14 and E7, while Fancd2 ${ }^{-/}$and 129/Sv cell lines were negative (Supplementary Table S6). Freshly removed epithelial squamous cell containing organs from K14E7 Fancd $2^{-/-}$mice including: skin, oral cavity, esophagus, and cervix were positive for both K14 and E7; however, other freshly removed organs including bone marrow were negative (Figure 5B). Furthermore, K14 and E7 negative tissues (other than marrow) cultured in medium supplemented with IL-3 for 4 weeks remained negative for detectable $\mathrm{K} 14$ and E7 (data not shown). Clonal K14E7 Fancd2 ${ }^{-/-}$cell lines grown in IL-3 were next tested for IL-3 independence, and all were IL-3 independent, factor-independent (F1) cell lines. In contrast, clonal K14E7 Fancd2 $2^{+/+}$, (129/Sv X FVB/n) F1 and Fancd $2^{-/}$cell lines remained IL-3 dependent. The K14E7 Fancd $2^{-/-}$clonal lines grew densely in culture (Figure 6A), and were positive for both K14 and E7 (Figure 6B).

We next injected K14E7 Fancd2 ${ }^{-/-}$clonal FI and other IL-3 dependent cell lines subcutaneously into the flank of adult mice at $1 \times 10^{6}$ cells in $100 \mu \mathrm{l}$ medium. Only the K14E7 Fancd2 ${ }^{-/}$FI cell lines formed tumors (Figure 6C, Table 4). The tumor histopathology showed both plasmacytoma (Figure 6D) and spindle cell sarcomalike (Figure 6E) regions. Cells from the same K14E7 Fancd $2^{-/-}$clone 1 cell line injected I.V. at $1 \times 10^{6}$ cells in $100 \mu \mathrm{l}$ formed multiple lung, liver, and soft tissue metastases, replaced the bone marrow with tumor cells, and produced peripheral blood leukemia with Ig kappa and lambda positive cells (not shown). The tumorinducing K14E7 Fancd2 ${ }^{-/}$clone 1 cell line (Figure 6F) and the tumors induced by this cell line (Figure 6G) were positive for both immunoglobulin kappa and lambda light chains, consistent with a plasma cell tumor. Lambda and kappa were upregulated and the ratio of lambda to kappa was increased. Since the K14E7 Fancd2 ${ }^{--}$clone1 derived tumor cell line was single cell in origin, the results establish that both kappa and lambda light chains, as well as the sarcoma morphology were found in the same clonal tumors. In contrast, K14E7 Fancd $2^{+/+}$adherent or IL-3 dependent nonadherent cell lines injected S.C. or I.V. produced no leukemia or solid tumors (not shown). These results establish that the E7 oncogene of HPV induced malignant transformation of bone marrow from K14E7 Fancd $2^{-/-}$mice when grown in LTBMCs in vitro.

\section{Novel phenotype of K14E7 Fancd2 ${ }^{-/}$LTBMC derived mouse plasmacytoma inducing cell lines}

The cell surface phenotype and immunohistochemical profile of the K14E7 Fancd2 ${ }^{--}$, IL-3 dependent, (which rapidly became IL-3 independent tumorigenic clonal cell lines (clone 1)) was markedly different from that observed with Fancd2 $2^{-/-}$(129/Sv) IL-3 dependent cell line. There was an increase in SCA1, from 2.3 to $97.5 \%$ positive. Collagen IV decreased from 27.7 to $0.5 \%$ (Table 5). The tumor-inducing K14E7 Fancd2 ${ }^{-/-}$, cell line had low levels of some markers of mesenchymal cells including osteoblasts (osteocalcin) and endothelial/ sarcoma (Collagen IV) (Table 5).

\section{Detection of E7, p53 and Rb in the nucleus of stromal and hematopoietic cell lines}

We tested K14E7 Fancd2 $2^{-/-}$malignant clonal lines, tumor cell lines removed form sites of solid tumors formed by K14E7 Fancd2 $2^{--}$clonal cells, and both LTBMCderived IL-3 dependent and stromal cell lines from each genotype for the nuclear and/or cytoplasmic location of $\mathrm{E} 7, \mathrm{p} 53$, and $\mathrm{Rb}$. Rb and p53 have been detected in nucleus and cytoplasm of many cell lines [68-69]. In stromal and IL-3 dependent cell lines from both K14E7 Fancd2 ${ }^{-/-}$and K14E7 Fancd2 ${ }^{+/+}$LTBMCs, but not Fancd2 ${ }^{-/-}$or $(129 / \mathrm{Sv}$ $\mathrm{X}$ FVB F1) cell lines, there was detectable nuclear E7, as well as both p53 and $\mathrm{Rb}$ (Figure 7A-7F). These results establish that while fresh whole marrow from K14E7 Fancd $2^{-/-}$mice was negative for K14 or E7 protein, both $\mathrm{K} 14$ and the K14 promoter linked E7 protein were detected in hematopoietic and stromal cell lines derived from LTBMCs. Furthermore, K14 and E7 positive cell lines were derived from both K14E7 Fancd2 ${ }^{+/+}$and K14E7 Fancd $2^{-/-}$mouse LTBMCs, while only IL-3 suspension culture grown cell lines from the latter became FI and induced tumors in vivo.

\section{E6/E7 plasmid transfection of Fancd2 ${ }^{-/-}$IL-3 dependent cell lines increases cloning efficiency and malignant transformation}

The above results establish that the E7 oncogene of HPV expressed in K14E7 Fancd2 $2^{-/}$marrow LTBMCs generated FI cell lines that produced malignant plasma cell tumors. The evolution of malignant cell lines in LTBMCs involved the presence of both mesenchymal stem cells 
Table 1: Radiosensitivity of K14E7Fancd2-/- marrow stromal cell lines

\begin{tabular}{|c|c|c|}
\hline Cell Line & Do (GY) & й \\
\hline K14E7 Fancd2 ${ }^{+++}$ & $1.48 \pm 0.05$ & $4.7 \pm 0.3$ \\
\hline \multirow{2}{*}{ K14E7 Fancd2 $2^{-/}$} & $1.52 \pm 0.15$ & $1.5 \pm 0.5$ \\
& $\mathrm{P} 1=0.84$ & $\mathrm{P} 1=0.01$ \\
\hline \multirow{2}{*}{$129 /$ Sv Fancd2 ${ }^{+/+}$} & $2.33+0.11$ & $3.5 \pm 0.1$ \\
& $\mathrm{P} 2=0.004$ & $\mathrm{P} 2=0.17$ \\
\hline \multirow{2}{*}{$129 /$ Sv Fancd2 $2^{-/}$} & $2.23+0.01$ & $1.9 \pm 0.3$ \\
& $\mathrm{P} 3=0.4970$ & $\mathrm{P} 3=0.030$ \\
& $\mathrm{P} 4=0.036$ & $\mathrm{P} 4=0.64$ \\
\hline
\end{tabular}

P1 compares the K14E7 Fancd $2^{-/-}$cell line to the K14E7 Fancd2 ${ }^{+/+}$cell line.

P2 compares the 129/Sv Fancd $2^{+++}$cell line to K14E7 Fancd2 $2^{+++}$cell line.

P3 compares $129 /$ Sv Fancd $2^{-/}$cell line to $129 /$ Sv Fancd $2^{+/+}$cell line.

P4 compares 129/Sv Fancd2 $2^{-/}$cell line to K14E7 Fancd $2^{-/}$cell line.

$P$ less than 0.05 shown in red.

Both Fancd $2^{-/-}$cell lines are more radiosensitive than their respective $F a n c d 2^{+/+}$cell lines as seen by the decreased n̆ which represents the shoulder on the survival curve (P1 and P3). Both of the K14E7 Fancd2 cell lines are more radiosensitive that their respective SV129 Fancd2 cell lines as seen the decreased $\mathrm{D}_{\mathrm{o}}(\mathrm{P} 2$ and $\mathrm{P} 4)$.

Table 2: Radiosensitivity of K14E7 Fancd2-- IL-3 dependent marrow culture-derived hematopoietic progenitor cell lines

\begin{tabular}{|c|c|c|}
\hline Cell Lines & $\mathrm{D}_{0}(\mathrm{~Gy})$ & $\tilde{\mathbf{n}}$ \\
\hline K14E7 Fancd2 ${ }^{+/+}$ & $1.86 \pm 0.06$ & $5.4 \pm 1.7$ \\
\hline K14E7 Fancd2 ${ }^{-/-}$ & $\begin{array}{l}1.37 \pm 0.12 \\
(p=0.025)\end{array}$ & $4.3 \pm 1.1$ \\
\hline 129/Sv Fancd $2^{+/+}$ & $1.08 \pm 0.06$ & $2.1 \pm 0.05$ \\
\hline 129/Sv Fancd2-- & $\begin{array}{l}2.02 \pm 0.11 \\
(p=0.0017)\end{array}$ & $\begin{array}{c}3.7 \pm 0.07 \\
(p=0.027)\end{array}$ \\
\hline
\end{tabular}

$p$-value compares K14E7 Fancd2 $2^{-/}$to K14E7 Fancd2 ${ }^{+/}$or 129/Sv Fancd2 ${ }^{-/-}$with 129/Sv Fancd2 $2^{+/+}$.

(stromal cells of the hematopoietic microenvironment), as well as hematopoietic progenitor cells. We next tested whether the E6 and E7 oncogenes of HPV could induce malignant transformation of hematopoietic cells independent of the marrow microenvironment. We utilized a plasmid containing both the E6 and E7 oncogenes of HPV and transfected Fancd $2^{-/}$and control IL-3 dependent hematopoietic progenitor cells in vitro as described in the Methods. Stromal and IL-3 dependent hematopoietic cell lines from each genotype culture were transfected with this plasmid containing both E6 and E7. Single cell derived clonal lines were selected for G418 resistance according to the methods. No difference in morphology or growth was detected with any transfected stromal cell lines (Table 6). Transfected compared to control IL-3 dependent transfected single cell derived cell lines were expanded from single cells in multiwell plates in medium containing IL-3, and then were again expanded in medium with no IL3.

In contrast to all other negative results, E6/E7 plasmid transfected IL-3 dependent Fancd $2^{--}$cells showed an increase in cloning efficiency and IL-3 independent (factor-independent FI) cell lines were derived, which formed tumors in vivo. Tumor forming lines were detected with 8 of 164 single cell derived clonal lines (Table 6). None of 8 control non-transfected and expanded Fancd2 single cell derived cell lines and no control or E6/E7 transfected Fancd2 ${ }^{+/+}$IL-3 dependent cell lines became IL-3 independent, and none formed tumors in vivo (Table 6). Therefore, Fancd $2^{-/}$hematopoietic cells could be transformed by E6/E7 of HPV in the absence of stromal cells of the hematopoietic microenvironment (Table 6).

\section{DISCUSSION}

The present studies demonstrate that the squamous cell lineage specific and restricted expression of E7 by the cytokeratin 14 promoter in K14E7 Fancd2 $2^{-/-}$mice was abrogated by growth of bone marrow in LTBMCs, LTBMC derived stromal and hematopoietic cells from K14E7 Fancd2 ${ }^{-/-}$mice expressed both K14 and E7. Furthermore, K14E7 Fancd2 ${ }^{-/-}$LTBMC derived IL-3 dependent cell lines, as well as freshly removed marrow hematopoietic progenitors were radiosensitive compared to those from Fancd $2^{-/-}$mice. The relative radiosensitivity 
A

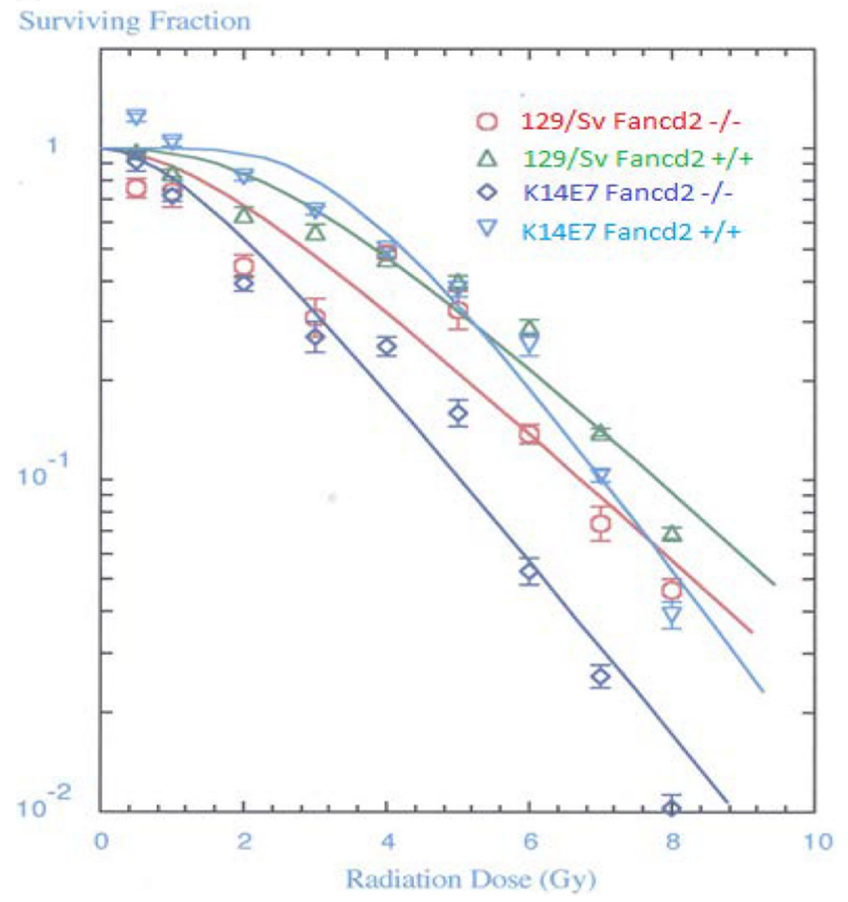

B

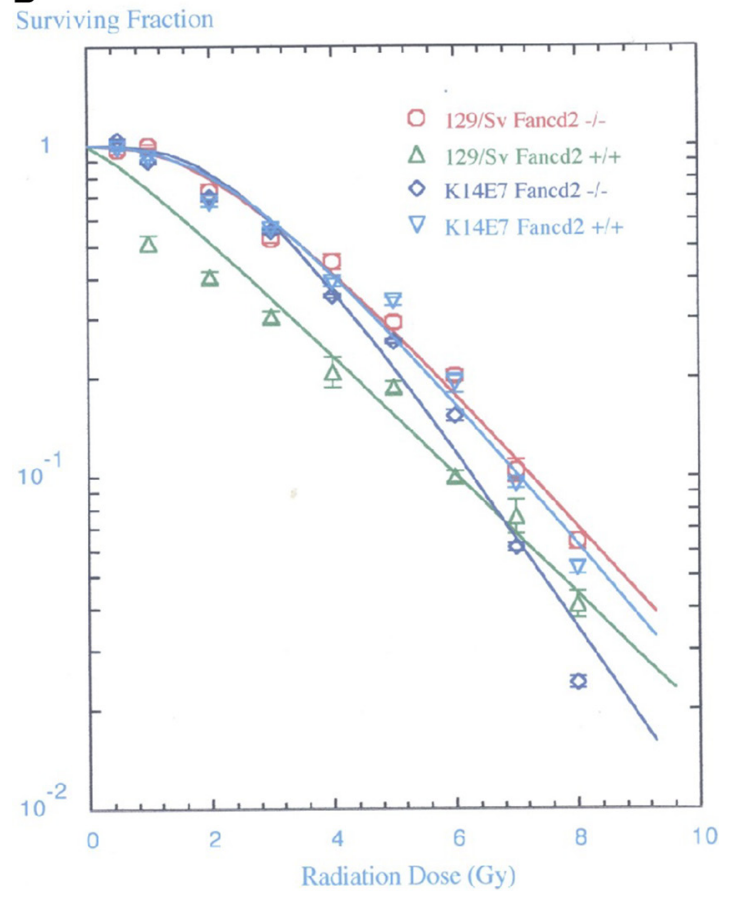

C

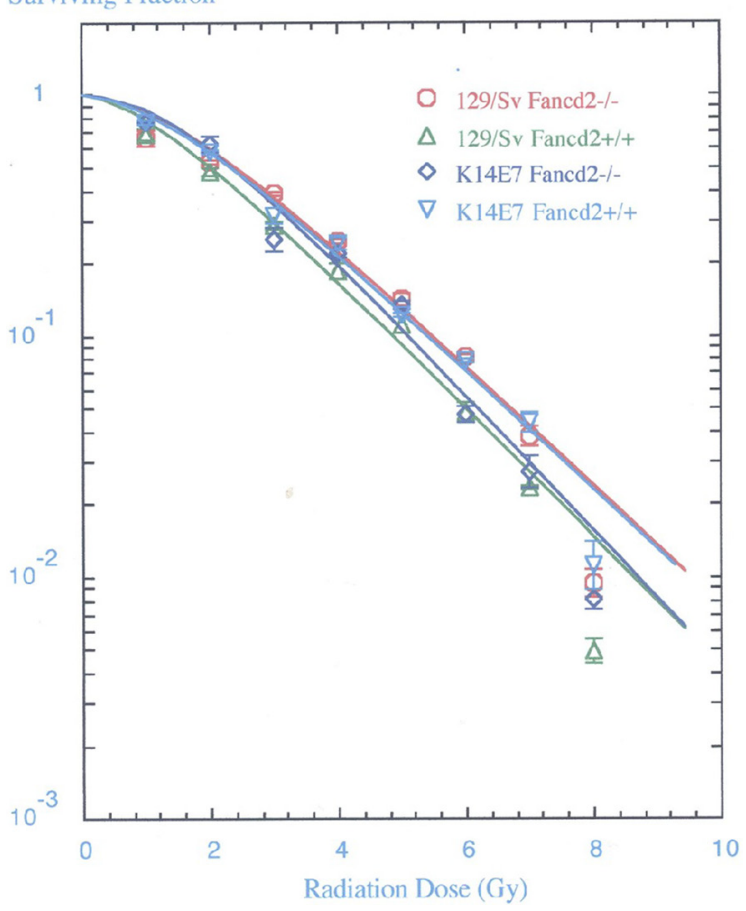

Figure 3: Radiosensitivity of clonogenic K14E7Fancd2 ${ }^{--}$bone marrow stromal and IL-3 dependent hematopoietic progenitor cell lines and fresh bone marrow. (A) Bone marrow stromal cell lines were established from the adherent layers of 4 week old LTBMCs. Clonal lines were isolated from long term bone marrow cultures established from groups of (FVB/N) K14E7 Fancd2 ${ }^{+/+}$, $(129 / \mathrm{Sv}) \mathrm{Fancd}^{-{ }^{--}},(129 / \mathrm{Sv})$ Fand2 $2^{++}$, and K14E7Fancd2 $2^{--}$mice. Stromal cell lines were established according to published methods [9]. The cell lines were irradiated to doses ranging from 0 to $8 \mathrm{~Gy}$, plated in 4 well Linbro plates, incubated for 7 days at $37^{\circ} \mathrm{C}$, stained with crystal violet, and colonies of greater than 50 cells were counted (Table 1). (B) Radiation sensitivity of IL-3 dependent cell lines was determined as published [9] (Table 2). (C) Fresh bone marrow was isolated from 6-8 wk old female K14E7 Fancd2 $2^{++}$, K14E7 Fancd2 ${ }^{-/}$, 129/Sv Fancd2 $2^{++}$, and 129/Sv Fancd2 $2^{-/}$mice. The CFU-GEMM assay scored at day 14 was carried out as described in the methods (Table 3). The data was analyzed using single-hit, multi-target models and linear quadratic models. 
Table 3: Radiosensitivity of K14E7 Fancd2-/- mouse fresh bone marrow CFU-GEMM

\begin{tabular}{|l|c|c|}
\hline \multicolumn{1}{c|}{ Fresh Marrow Source } & Do $(\mathbf{G y})$ & n \\
\hline K14E7 Fancd2 & $\begin{array}{l}1.84 \pm 0.04 \\
(p=0.075)\end{array}$ & $5.6 \pm 2.8$ \\
\hline K14E7 Fancd2 & $\begin{array}{l}1.47 \pm 0.07 \\
(p=0.039)\end{array}$ \\
\hline 129/Sv Fancd2 & $1.4 \pm 0.3$ \\
\hline 129/Sv Fancd2 & $1.4 \pm 0.15$ & $3.5 \pm 1.5$ \\
\hline
\end{tabular}

$p$ value compares K14E7 Fancd2 $2^{-/}$to K14E7 Fancd2 ${ }^{+/+}$or $129 / \mathrm{Sv}$ Fancd2 $2^{-/}$to $129 / \mathrm{Sv}$ Fancd2 ${ }^{+/+}$.

Table 4: Tumor formation by K14E7 Fancd2-- bone marrow culture derived cell lines

\begin{tabular}{|c|c|c|c|c|}
\hline $\begin{array}{c} \pm 13 \text { Dependent } \\
\text { Cell Line }\end{array}$ & $\begin{array}{c}\text { Morphology in } \\
\text { Culture }\end{array}$ & $\begin{array}{l}\text { No. Cells } \\
\text { Injected }\end{array}$ & No. Tumors/No. Mice & $\%$ \\
\hline Fancd2 $2^{-/-}(129 / \mathrm{Sv})$ & $\mathrm{H}$ & $10^{7}$ & $0 / 10$ & 0 \\
\hline $\begin{array}{l}\text { K14E7 (FVB) } \\
\text { Fancd2 }^{+/+}(129 / \mathrm{Sv})\end{array}$ & $\mathrm{H}$ & $10^{7}$ & $0 / 10$ & 0 \\
\hline K14E7 Fancd2 $2^{-/-}$ & $\mathrm{B}$ & $10^{7}$ & $1 / 5$ & 60 \\
\hline K14E7 Fancd2-/- Clone 1 & $\mathrm{~B}$ & $10^{7}$ & $3 / 5$ & 20 \\
\hline K14E7 Fancd2 ${ }^{-/}$Clone 5 & $\mathrm{~B}$ & $10^{7}$ & $2 / 4$ & 50 \\
\hline K14E7 Fancd2 ${ }^{-/-}$Clone 6 & $\mathrm{~B}$ & $10^{6}$ & $3 / 5$ & 60 \\
\hline K14E7 Fancd2 $2^{-/-}$Clone 8 & $\mathrm{~B}$ & $10^{6}$ & $1 / 5$ & 20 \\
\hline
\end{tabular}

$\mathrm{H}=$ Hematopoietic Nonadherent.

$\mathrm{B}=$ Bilineage Adherent and Nonadherent Cells, as in Figure 4C.

A

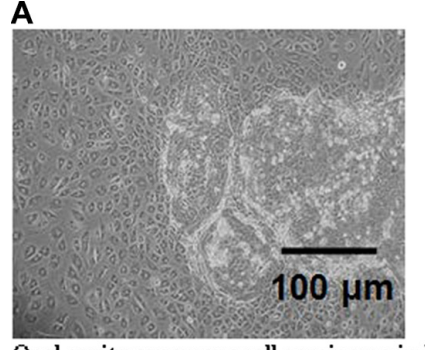

Oral cavity squamous cell c arcinoma in Kl4E $7 \mathrm{Facd} 2-/-$ mice at 10 weeks after 4NQO treated and 22 weeks on norm al water. (A) in situ; (B) $\mathrm{H} \& \mathrm{E}$ stain.

C

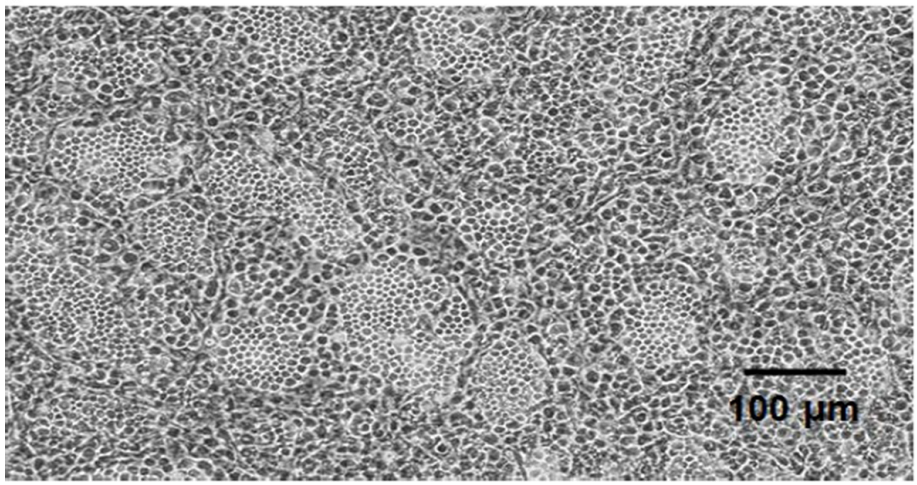

Figure 4: Comparison of morphology of explanted oral cavity tumor from a 4-NQO treated K14E7 Fancd2 ${ }^{-/}$mouse with IL-3 cultured cells from LTBMCs. (A) Oral cavity tumor explanted in culture for 4 weeks; (B) original oral cavity tumor in situ (H \& E stained); (C) cultured, clonal, nonadherent hematopoietic cells from K14E7 Fancd2 ${ }^{-/}$mouse 12 weeks in $100 \mu \mathrm{M}$ IL-3 after harvest from 4 wk old LTBMC. 
Table 5: Immunohistochemical phenotype of tumorigenic cell line K14E7 Fancd2 ${ }^{-/-}$clone 1

\begin{tabular}{|c|c|c|c|}
\hline Antibody & Known Cell Type Positive & $\begin{array}{c}\text { K14E7 } \\
\text { Fancd2-- }^{-/} \\
\text {Clone } 1 \\
\text { (\% positive) }\end{array}$ & 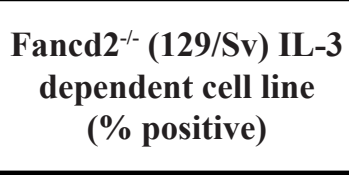 \\
\hline CD3e & NK, NKT, T, Th17, and Treg cells & 26.4 & 0.3 \\
\hline CD5 & $\mathrm{B}$ and $\mathrm{T}$ cells & 29.0 & 1.5 \\
\hline $\mathrm{CD} 8$ & $\mathrm{NK}, \mathrm{NKT}$, and T cells & 43.5 & 0.8 \\
\hline B220 & $\mathrm{B}$ and $\mathrm{T}$ cells & 32.4 & 1.0 \\
\hline GR-1 & Macrophage and Monocyte cells & 17.5 & 0.0 \\
\hline TER-119 & Erythroid cells & 11.8 & 0.1 \\
\hline CD41 & Hematopoietic Stem cells & 0.1 & 0.0 \\
\hline CD45 & $\begin{array}{l}\text { Hematopoietic cells except erythrocytes } \\
\text { and platelets }\end{array}$ & 17.2 & 100.0 \\
\hline CD48 & NK, NKT, and T cells & 7.3 & 14.0 \\
\hline SCA-1 & Hematopoietic Progenitor/Stem cells & 97.5 & 2.3 \\
\hline C-KIT & Hematopoietic Progenitor/Stem cells & 99.6 & 100.0 \\
\hline CD150 & $\mathrm{B}, \mathrm{T}$, Dendritic cells & 7.3 & 1.1 \\
\hline Vimentin & Fibroblasts & 54.8 & 51.1 \\
\hline Actin & Muscle & 4.5 & 55.6 \\
\hline Adiponectin & Adipocytes and Pre-Adipocytes & 7.0 & 8.3 \\
\hline Collagen III & Fibroblasts & 10.3 & 18.8 \\
\hline Collagen IV & Endothelial cells & 0.5 & 27.7 \\
\hline Osteopontin & Osteoblasts & 12.1 & 3.6 \\
\hline Osteocalcin & Osteoblasts & 0.2 & 0.6 \\
\hline
\end{tabular}

A
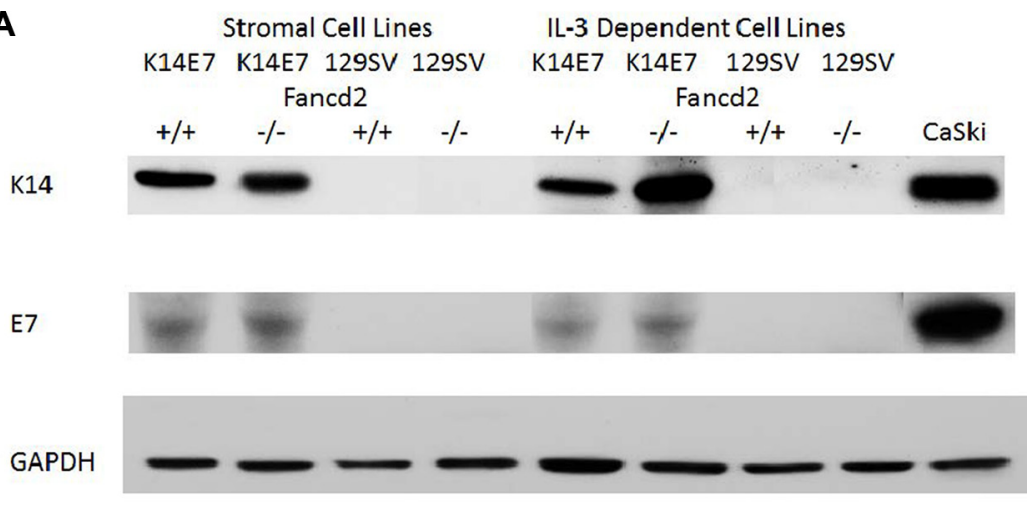

B

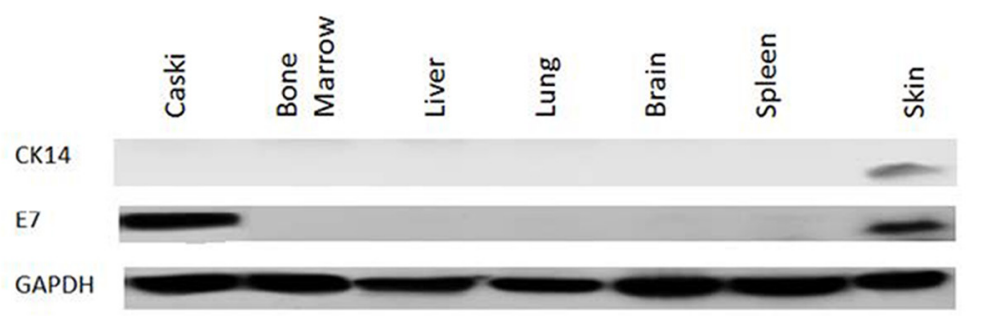

Figure 5: Detection of K14 and E7 proteins by Western blot in fresh tissues and in bone marrow stromal and IL-3 dependent cell lines derived from K14E7Fancd2 ${ }^{--}$mice LTBMCs. (A) Cell lines of bone marrow stromal compared to IL-3dependent cell lines; and (B) Fresh explanted tissues $(100 \mu \mathrm{M})$ for 4 weeks. 
of K14E7 expressing hematopoietic cells was comparable to that reported for other oncogene [71], FA pathway $[9,73]$, or other double strand break repair gene altered cell lines including those from ATM mice [72].

Unexpectedly, K14E7 Fancd2 $2^{-/}$LTBMC derived hematopoietic cells subcultured in IL-3 produced clonal malignant plasmacytoma cell tumors. K14E7 Fancd2 $2^{-/-}$ mice are known to develop squamous cell tumors of the oral cavity and the female cervix [26], but in this model, either oral chemical carcinogen or estrogen pellet placement respectively was also required for carcinogenesis. In the present studies, untreated K14E7 Fancd $2^{-/}$marrow in LTBMC and subcultured nonadherent cells grown in the presence of IL-3 spontaneously

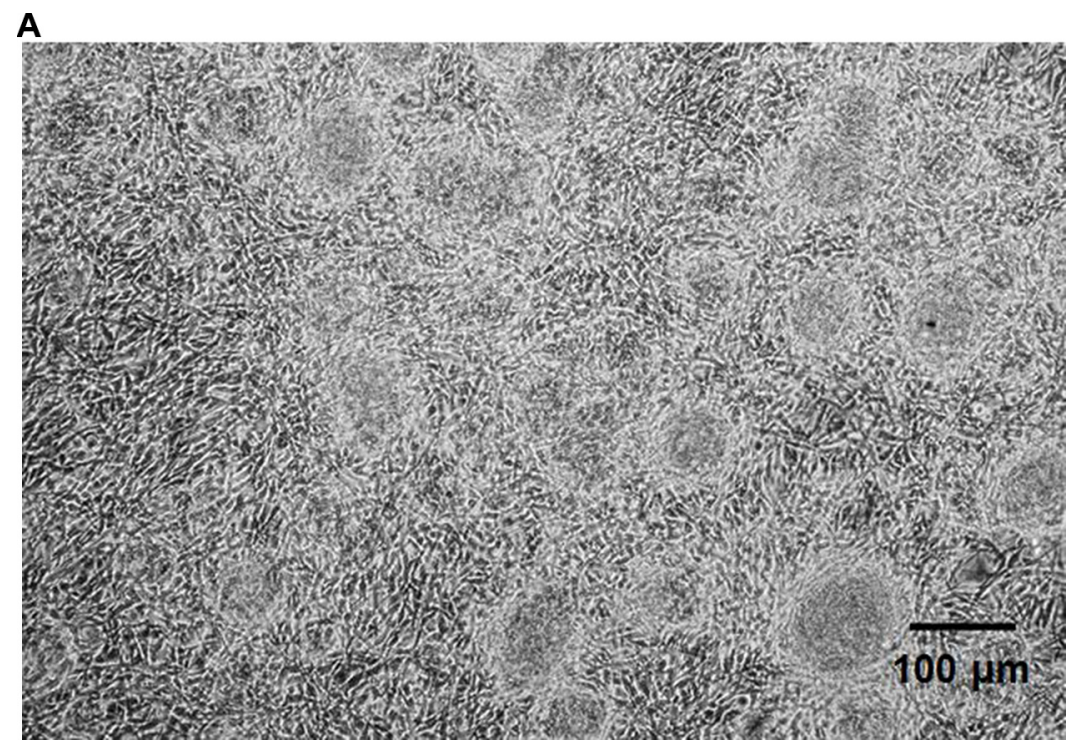

B

A. K14E7 Fancd2 ${ }^{-/-}$Clone 1

E7

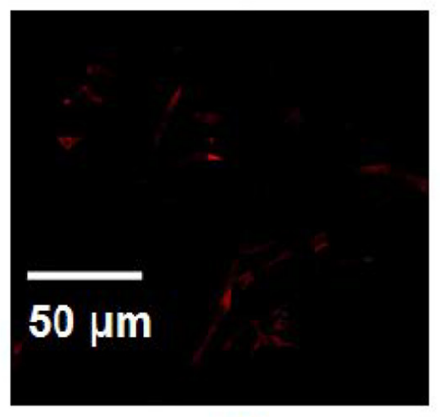

K14
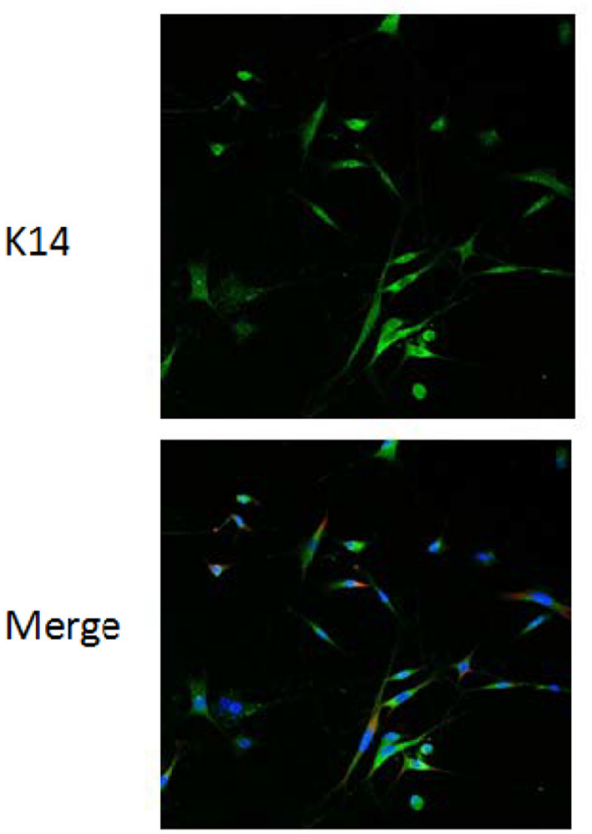
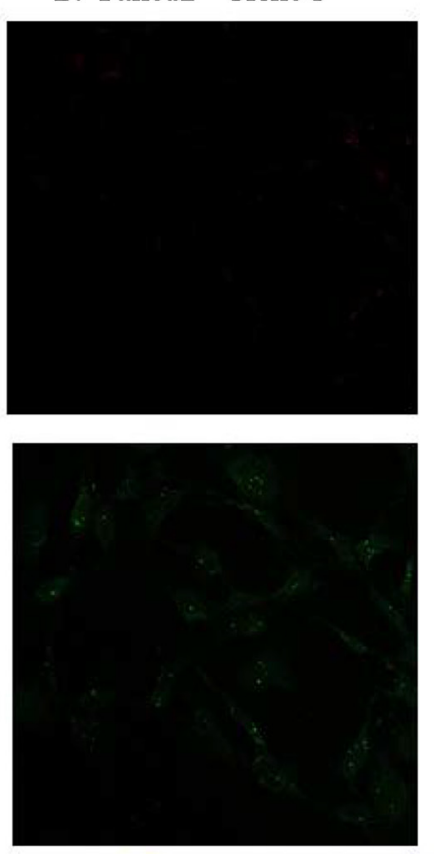

B. Fancd ${ }^{-/-}$Clone 5

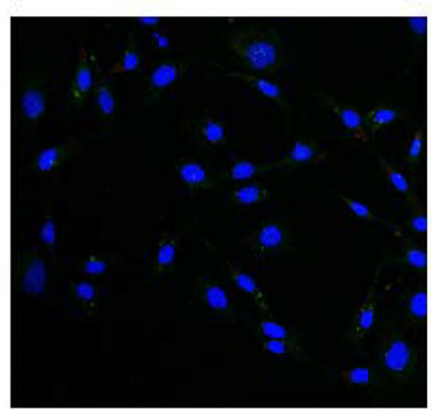


C

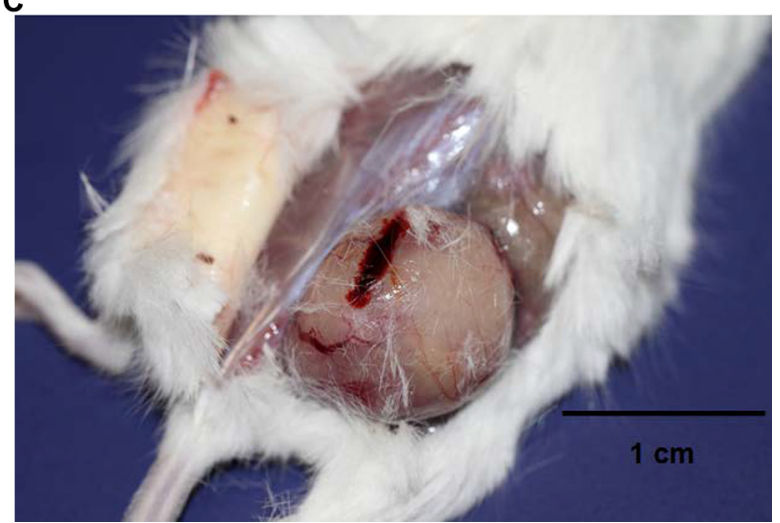

E

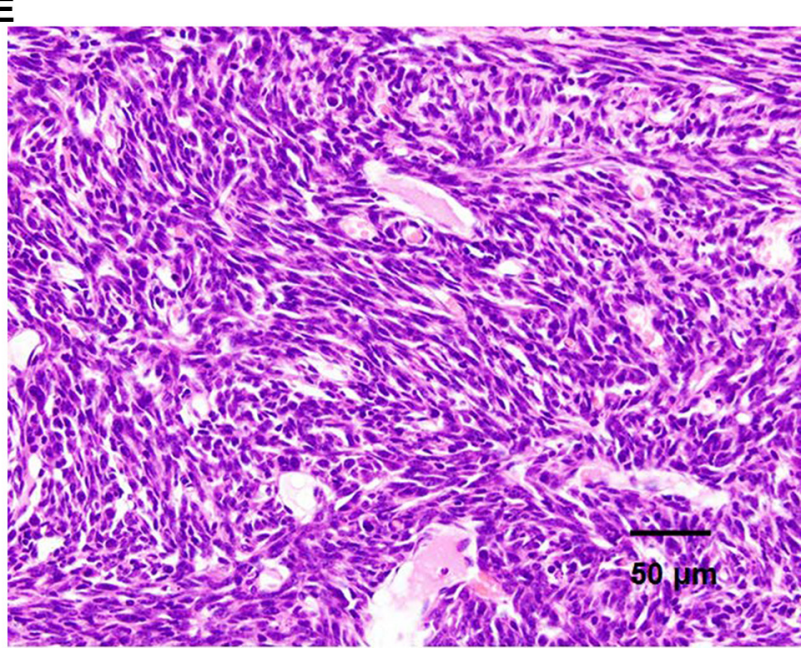

\section{D}

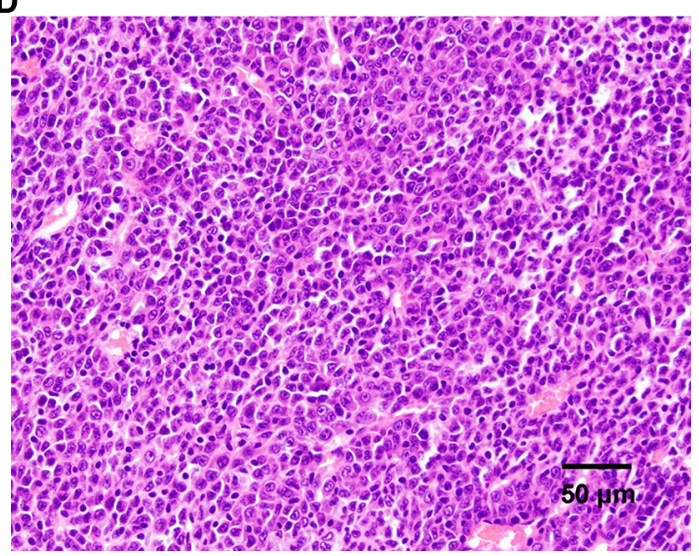

$\mathbf{F}$

3LL(lewis lung carcinoma)

K14E7 FancD2-/-clone 1
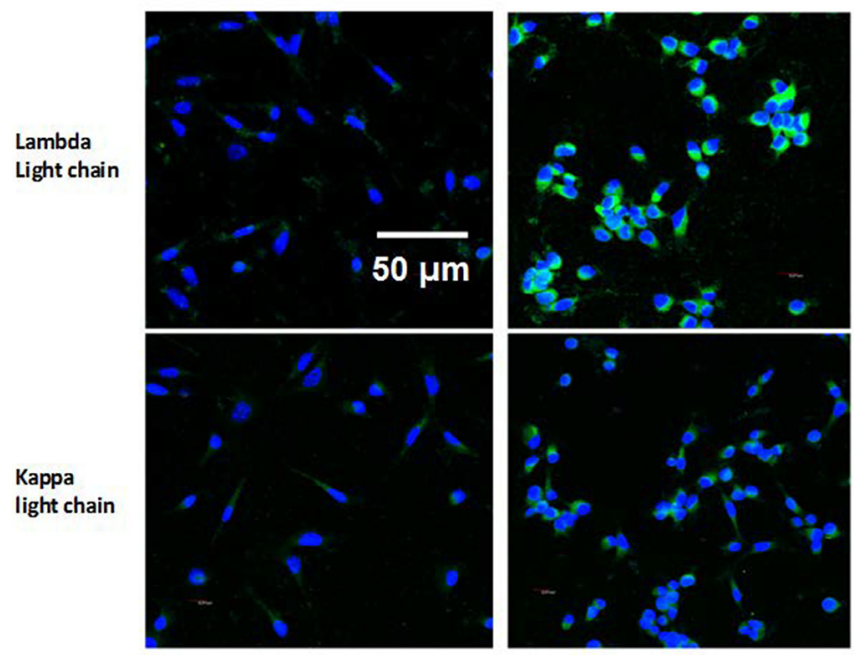

G

No primary antibody

LAMBDA Light Chain
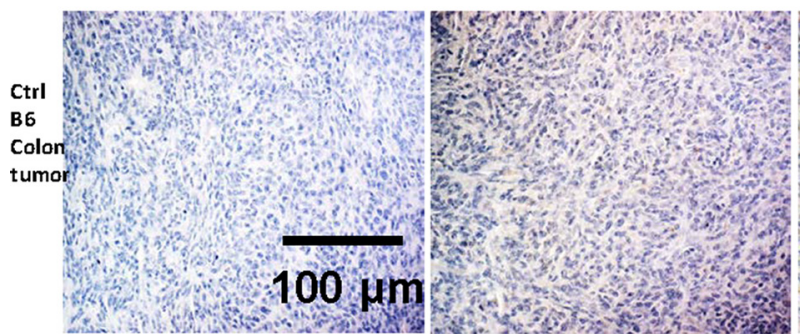

KAPPA Light Chain
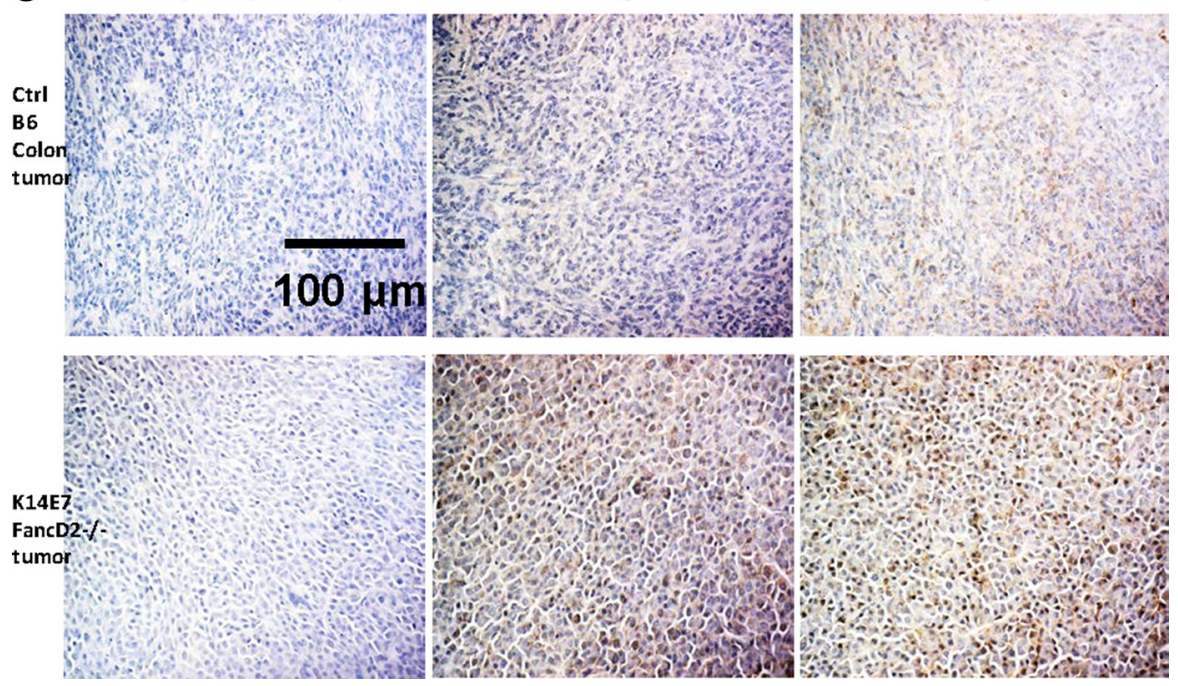

Figure 6: Morphology and immunohistochemistry for immunoglobulin kappa and lambda light chain in K14E7 Fancd2 ${ }^{-/}$clone 1 IL-3-dependent tumor forming cell lines. (A) in vitro appearance of FI (no IL-3) clonal cell line K14E7 Fancd2 $2^{-/}$clone 1; (B) cytokeratin-14 (K14-green) and E7 (red) positivity of K14E7 Fancd2 ${ }^{-/}$clone 1, Blue nucleus-DAPI-stain compared to control Fancd2 $2^{-/}$clone 5; (C) tumor formed in flank of mouse at wk 4 after injection with $10^{6} \mathrm{~K} 14 \mathrm{E} 7 \mathrm{Fancd} 2^{-/}$clone 1 cells; and (D) H\&E stained tumor-plasmacytoma appearing area from tumor in panel C; and $\mathbf{E}$ ) sarcoma appearing area in same tumor as in panel (D). (F) Immunoglobulin K and B light chain positivity of cells from K14E7 Fancd2 $2^{-\leftarrow}$ clone 1 cell line; (G) immunoglobulin light chain kappa and lambda positive tumor induced in vivo by K14E7 Fancd2 ${ }^{--}$clone 1 cell line (tumor from panel C) negative control Lewis Lung Carcinoma (3LL) cell line [67]. 
transformed to malignant plasmacytoma cell lines. We confirmed that K14E7 Fancd $2^{-/-}$mice treated with oral 4-NQO developed squamous cell tumors of the oral cavity and esophagus, but we saw no detectable effect of oral 4-NQO treatment of these tumor bearing mice on malignant transformation of their explanted bone marrow in LTBMCs.

The reduction in day 7 and day 14 colony forming cells in 4-NQO treated mouse, as well as in control mouse, K14 Fancd2 2 $^{--}$LTBMCs was probably related to the reduction in stem cell numbers that was associated with the Fancd $2^{-/}$genotype, prior chemical treatment and/or the malignant transformation of oral cavity that was in progress. In contrast, the effect of K14E7 expression in K14E7 Fancd2 ${ }^{+/+}$marrow cultures may have caused an increased cell production response, perhaps reflecting the effect of an intact Fancd 2 gene with associated intact DNA repair. It is possible that the hydrocortisone added to LTBMC medium [28] and/or IL-3 added weekly to the subculture medium may have facilitated activation of

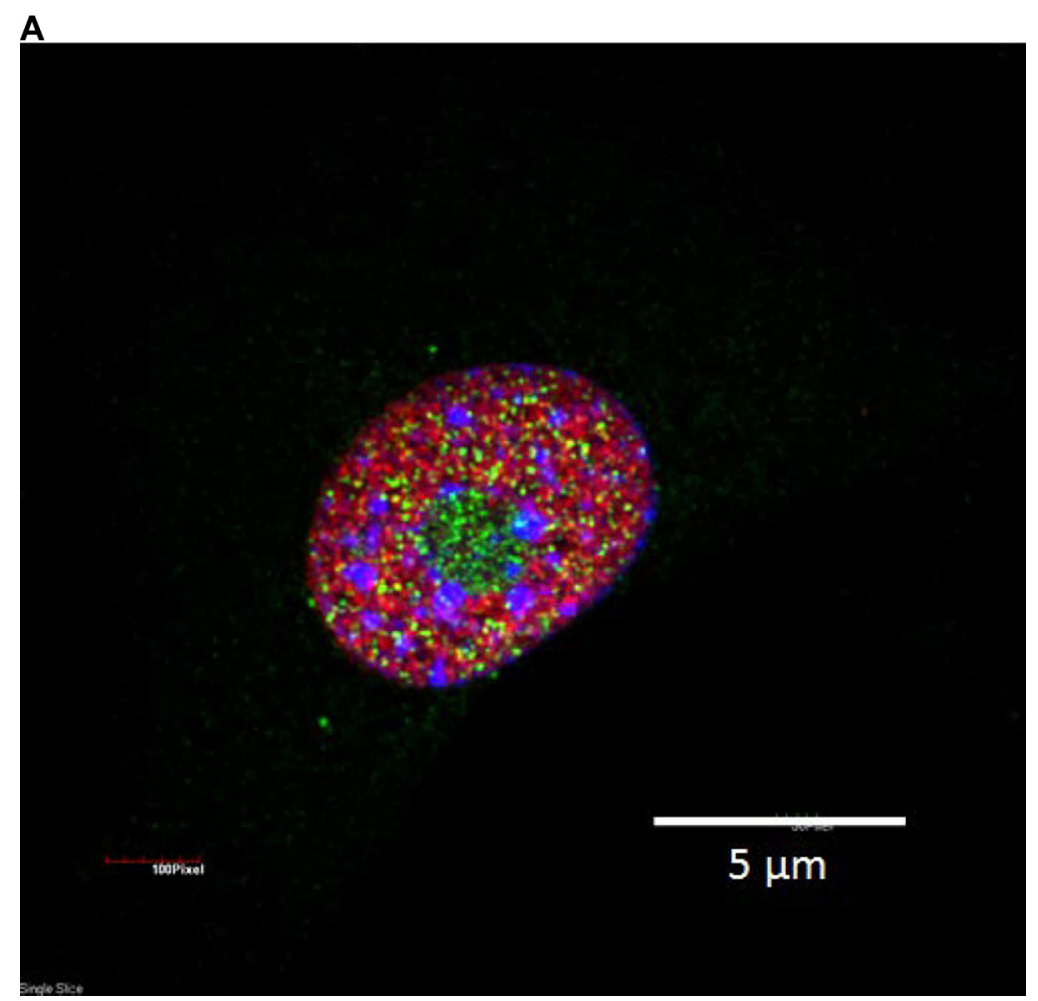

B K14/E7 SV129 BM IL-3 dependent FancD2-/- cells staining with Rb and E7, E7 has co-

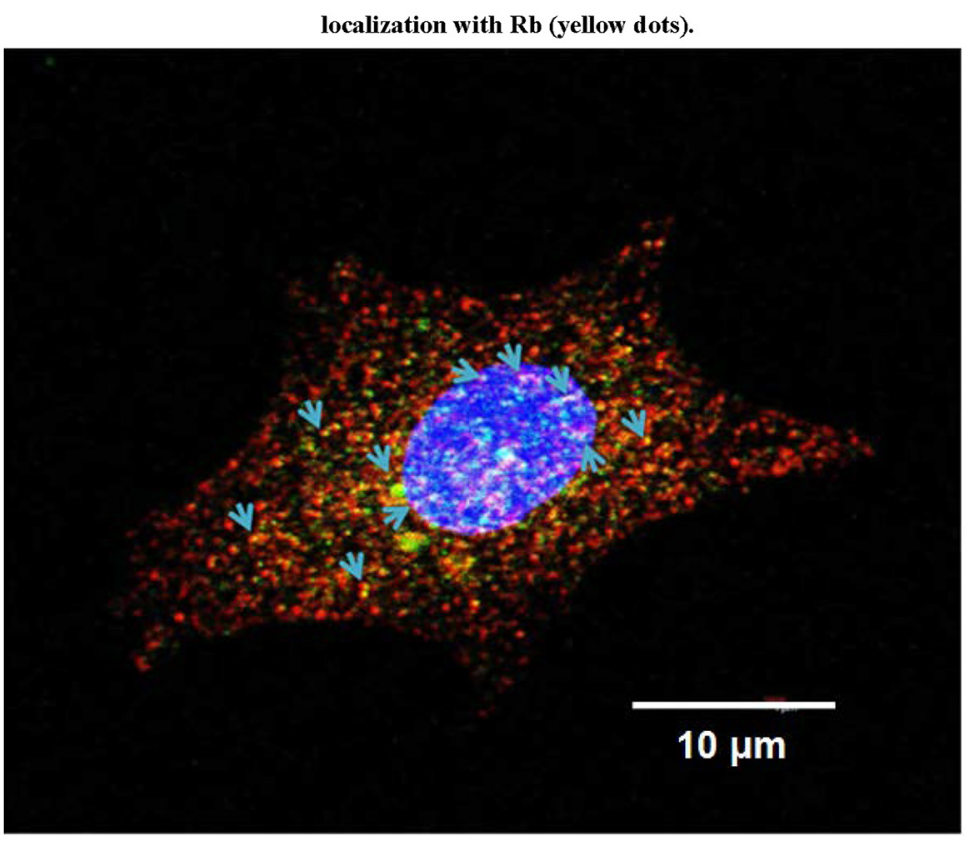



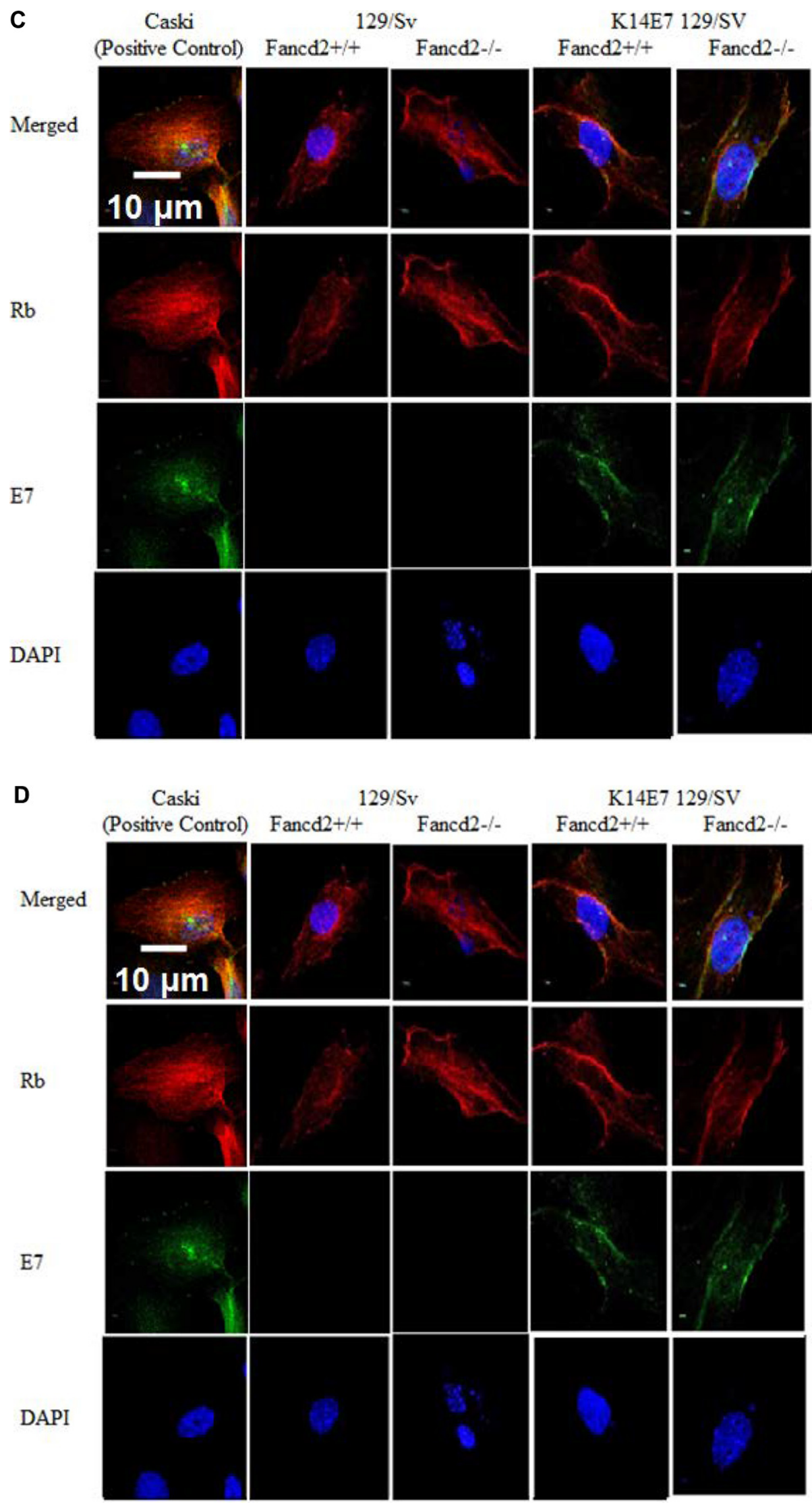
E

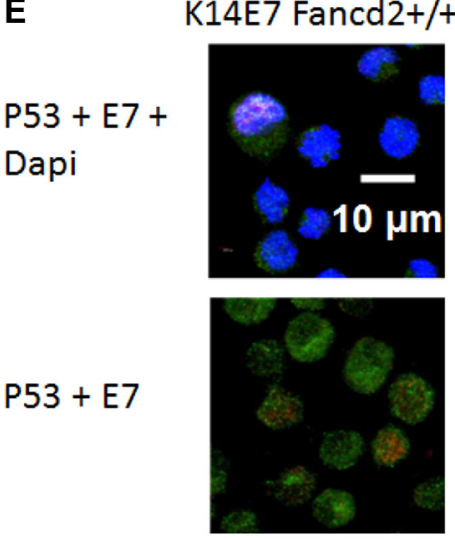

P53

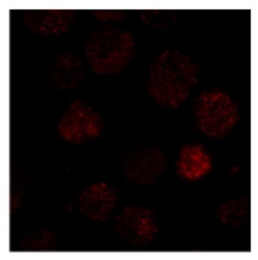

E7

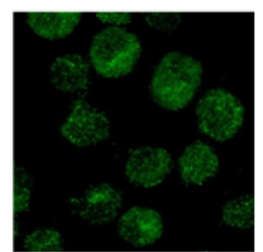

K14E7 Fancd2 -/-
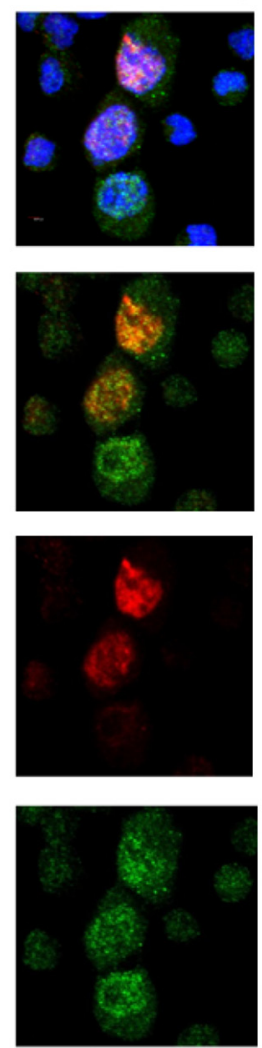

$\mathbf{F}$

$\mathrm{Rb}+\mathrm{E} 7+$

Dapi
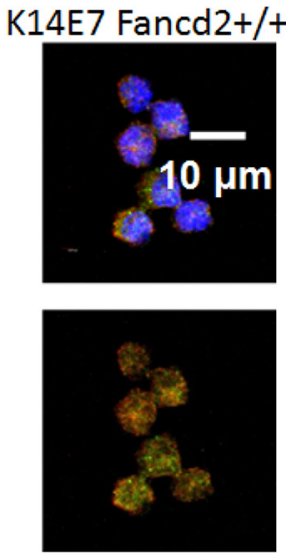

$\mathrm{Rb}$

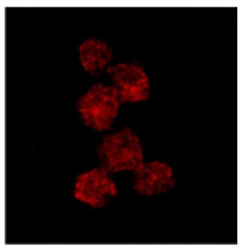

E7

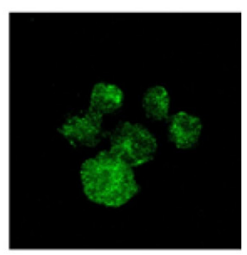

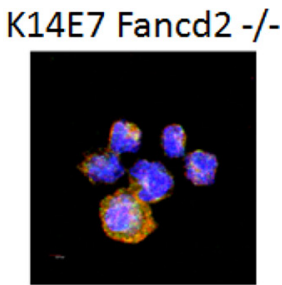
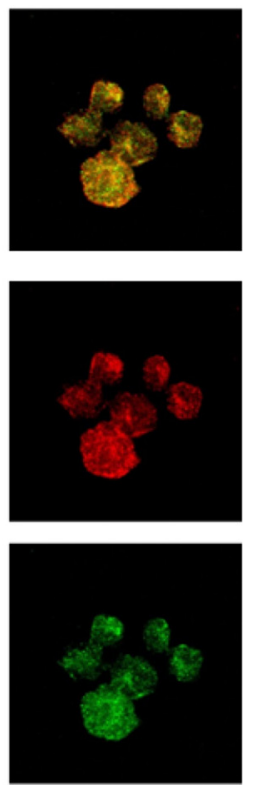

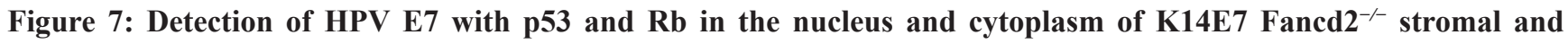
hematopoietic cell lines. (A) E7 and p53 detection in the nucleus of K14E7 Fancd2 ${ }^{-/}$clone 1 cells (nucleolus is green). Detection of E7 with p53 (yellow dots); (B) E7 and Rb detection in the nucleus and cytoplasm of K14E7 Fancd2 ${ }^{-/}$clone 1 cells (nucleus is blue). E7 detected with Rb (yellow dots); (C) p53 with E7 in stromal cell lines ( $\times$ 500); (D) Rb with E7 in stromal cell lines; (E) p53 with E7 in IL-3 dependent hematopoietic cell line; (F) Rb with E7 in IL-3 dependent hematopoietic cell lines.

the K14 promoter linked E7 expression in hematopoietic cells from K14E7 Fancd2 ${ }^{-/}$and K14E7 Fand2 ${ }^{+/+}$mice; however, the Fancd $2^{-/-}$genotype was clearly required for malignant transformation of hematopoietic cells to plasmacytomas.

There was clearly an hematopoietic lineage specific biologic effect of adding the K14E7 genotype to Fancd2 $2^{-/}$ marrow cells when maintained in LTBMCs. Freshly removed organs from K14E7 Fancd $2^{-/-}$mice revealed E7 expression only in those tissues where cytokeratin 14 was naturally expressed, including: oral cavity, esophagus, skin, and cervix. There was no detectable K14 or E7 expression in kidney, liver, bone marrow, or spleen, even when these organs were explanted and grown in IL-3 containing medium for over 4 weeks. While LTBMC derived K14E7 Fancd2 ${ }^{-/}$and K14E7 Fancd2+/+ cell lines showed expression of CK14 and its linked E7 oncogene protein in both marrow stromal and hematopoietic cells, only hematopoietic cell lines from the former generated malignant plasmacytoma cell lines in vitro.

The pattern of secondary growth of K14E7 Fancd2 $2^{-/-}$ mouse nonadherent cells subcultured in IL-3 supplemented cultures was not detected with marrow from any of the other genotypes studied in the current experiments nor in prior publications [9-10]. The novel secondary culture growth pattern was also not observed with LTBMCs from over 28 other mouse strains [28]; nor has it been observed in leukemogenic retroviral or chemical carcinogen treated mouse LTBMCs [30-37].

The present K14E7 Fancd $2^{-/}$malignant plasmacytomas derived from single cells expressed both kappa and lambda light chains, a phenomenon known to occur in human multiple myelomas [52]. Thus, the present results establish that expression of both light chains does not indicate a polyclonal tumor. Tumor cell lines, as well as IL-3 dependent cell lines derived of K14E7 Fancd2-/long-term cultures showed E7 binding to both nuclear $\mathrm{p} 53$ and $\mathrm{Rb}$. While location of the E7 oncogene protein along with p53 and Rb was detected in the nucleus of K14E7 Fancd $2^{-/-}$LTBMC derived plasmacytoma tumor cell lines, we cannot conclude that these conditions were sufficient for malignant transformation, since non-tumorigenic stromal cell lines from K14E7 Fancd2 ${ }^{+/+}$mouse marrow cultures also showed nuclear location of these proteins. Direct transfection of IL-3 dependent, non-malignant cell lines derived from Fancd $2^{--}$long-term cultures with 
Table 6: E7 plasmid transfection of Fand2-- ${ }^{-}$IL-3 dependent cell line increases in vitro cloning efficiency

\begin{tabular}{|c|c|c|}
\hline Cell Line & Single Cell Cloning Efficiency & $\begin{array}{c}\text { Malignant Transformation of Expanded } \\
\text { Single Cells }\end{array}$ \\
\hline \multicolumn{3}{|l|}{ Stromal Cell Lines: } \\
\hline K14E7 Fancd2 ${ }^{-/-}$ & $52 / 400$ & $0 / 400$ \\
\hline K14E7 Fancd2 ${ }^{+/+}$ & $48 / 400$ & $0 / 400$ \\
\hline Fancd $2^{-/-}$ & $44 / 400$ & $0 / 400$ \\
\hline$(129$ X FVB) F1 & $48 / 400$ & $0 / 400$ \\
\hline $\begin{array}{l}\text { IL-3 Dependent Subclonal Cell Lines } \\
\text { (Plasmid Transfected): }\end{array}$ & (Control-Non-Transfected) & \\
\hline Fancd2 $2^{-/-}$(PLXSN16E6E7) & $* * 164 / 400(8 / 400)$ & $* * 8 / 164(0 / 8)$ \\
\hline K14E7 Fancd2 ${ }^{+/+}$ & $8 / 400(6 / 400)$ & $0 / 8(0 / 6)$ \\
\hline$(129$ X FVB) F1 & $6 / 400(11 / 400)$ & $0 / 6(0 / 11)$ \\
\hline
\end{tabular}

Adherent stromal and IL-3 dependent cell lines were transfected with PLXSN16E6E7 plasmid, as described in the methods. Then, each of 400 single cells was plated in multi-well plates (in Il-3 containing medium). The number of cells containing a proliferating cell line was scored 7 days later. IL-3 dependent cell lines were then expanded in medium without IL-3. IL-3 independent (factor independent-FI) cell lines were those continuing to divide in the absence of IL-3.

${ }^{* *} p<.001$ compared to non-transfected Fancd $2^{-/-}$cell line.

a plasmid containing both E6/E7, transformed 8 of 164 single cells to factor independence and the malignant phenotype. Increased growth and migration capacity, but not malignant transformation has been detected in KRAS transfected cord blood cells [70]. Whether hematopoietic growth factors other than IL-3 also stimulate malignant transformation of subcultured K14E7 Fancd $2^{-/-}$marrow cells from LTBMCs is not known. The clonal nature of K14E7 Fancd2 $2^{-/}$cells with bilineage differentiation capacity was detected in 10 separate single cell derived subclonal lines. No bilineage clonal IL-3 dependent cell lines have been detected in LTBMCs from other mouse strains or with K14E7 Fancd2 $2^{-/-}$clonal cell lines grown in G-CSF, GM-CSF, IL-6, or IL-11 (not shown). Malignant plasmacytoma cell lines in our studies were growth factor independent. Recent data indicates that at least 12 different genes in the JAK/STAT and MAP Kinase pathways can induce transposon mutagenesis of IL-3 factor dependent cell lines to factor independence [66]. Whether the E7 oncogene in the absence of the Fancd 2 protein induced these or other genes in our LTBMC derived cell lines is not known. Whether the E7 or E6 oncogene alone transforms IL-3 dependent Fancd $2^{-/}$cell lines to malignant FI cell lines is not known since the plasmid used contained both oncogenes. Further studies will be required to determine if E7 (or E6) alone is sufficient for malignant transformation of Fancd $2^{-/-}$hematopoietic cells in the absence of stromal cells found in LTBMCs.

Complex effects of the HPV E6 and E7 oncogene in cell killing have been described [53-64]. A role for HPV E7 interaction with p53 has been shown in malignant transformation in that degradation of $\mathrm{p} 53$ was required for malignant transformation by HPV E6/E7 [65].
Whether degradation of p53 occurred in the malignant plasmacytoma cell lines derived from K14E7 Fancd2 ${ }^{-/-}$ long-term marrow cultures is not known.

The present studies expand the possible cell target of HPV E7 to include the bone marrow in patients with FA. Replication of HPV has recently been shown to require DNA repair by homologous recombination (HR) and involving RAD51 and BRCA1 [23]. The HR pathway is known to be downregulated in FA cells, which are also sensitive to the effects of TGF- $\beta$ [25]. There is published evidence that HPV alters hematopoietic cells. Plasma cell dyscrasias have been detected in patients with HPV infection [38], and patients with multiple myeloma have been shown to be HPV positive [39-40]. There is also evidence, which links HPV expression with malignant transformation of B-cell progenitors in the marrow, by cotransfection of HPV E7 or other oncogenes [41]. Human bone marrow cell lines expressing HPV16 E6 and E7 showed in vitro support capacity for hematopoiesis [43]. HPV16 E6/E7 immortalized human marrow stromal cell lines that support hematopoiesis showed integration of the E6/E7 vector into the cellular genome [43].

Fresh human bone marrow derived mesenchymal stem cells have been reported to become radiosensitive after HPV-16 E6/E7 transfection [44], and showed reduced DNA double strand break repair capacity and increased apoptosis. HPV mRNA expression has been detected after transfection of many other cell phenotypes including: mesenchymal stem cells [45], prostate cancer cell lines [46], keratinocytes [47], and dendritic cells [48]. Bone marrow transplantation has resulted in the transmission, from marrow of P16/human HPV to graft recipients resulting in oral squamous cell carcinoma 
[13]. While prior studies have shown that the E7 gene product activates multiple cell signaling pathways [24], malignant transformation of B-cell progenitor cells in vitro has not been reported. Evolution of B-cell and plasmacytoma-inducing tumors from adherent cells in culture has been reported with Epstein-Barr virus [49], and B-cell progenitors are known to reside in the adherent layer of long-term marrow cultures and can proliferate over time [50]. The Friend Spleen Focus Forming Virus (SFFV) expands hematopoietic islands in LTBMCs [51]; however, we detected no evidence of stem cell expansion in the present studies with HPV E7. The mechanism by which HPV E7 induces radiation sensitivity of hematopoietic cells and malignancy in K14E7 Fancd2 $2^{-/-}$mouse marrow cultures is not known. Further studies will be required to determine whether the condition(s) of LTBMC and/or IL-3 suspension culture are required for malignant transformation with HPV-E7 transfected freshly removed marrow stem cells from K14E7 Fancd2 ${ }^{-/-}$mice. The present results on the biology of K14E7 Fancd2 ${ }^{-/}$marrow in LTBMCs provide a new system in which to study effects of HPV on: 1) the mechanism of HPV E6/7 genes in tumorigenesis in an in vitro organ culture system; 2) the mechanism of the K14 promoter control of expression of E7 in mesenchymal and hematopoietic cells in culture; and 3) the effect of an absent Fancd2 protein on expansion of a subpopulation of primitive adult bone marrow cells to both hematopoietic and mesenchymal stromal cell phenotypes.

Fanconi Anemia patients may be at increased risk of cell transformation by HPV, in part attributable to defective DNA repair $[6,15,53]$. Fancd $2^{-/}$mice of both the 129/Sv [10] and C57BL/6J [9] background strains demonstrate significant radiosensitivity. Clinical radiotherapy patients with HPV positive head and neck cancers have been reported to have tumor control by lower radiation doses [17]. While both Fancd $2^{-/}$and K14E7 Fancd $2^{-/-}$marrow stromal lines in our studies were radiosensitive, only Fancd $2^{-/-}$hematopoietic cell lines and fresh marrow colony forming progenitor cells were radioresistant. These data indicate that the Fancd2 protein has phenotype-specific effects on the ionizing irradiation response. The present data demonstrate that the E7 oncogene of HPV transforms Fancd $2^{-/-}$hematopoietic cells in LTBMCs to malignant plasma cell tumors, and extend the spectrum of potential effects of HPV to the bone marrow of genetically susceptible patients with DNA repair defects including those with Fanconi Anemia.

\section{MATERIALS AND METHODS}

\section{Mice}

Fancd $2^{-/-}$, Fancd2 $2^{+/}$, and Fancd $2^{+/+} \quad(129 / \mathrm{Sv}$ background [1]) and K14E7 mice (FVB background [26]) were generously provided by Dr. Paul Lambert (University of Wisconsin, Madison, WI). Mice were bred according to published methods to produce K14E7Fancd $2^{-/-}$mice [26] as published.

\section{4-nitro-quinolone-oxide (4-NQO) treatment}

In subgroups of mice, the addition of 4-nitroquinolone oxide (4-NQO) (Sigma Chemical Company, St. Louis, MO) to drinking water was carried out as published [14]. Briefly, 4-NQO $(10 \mu \mathrm{g} / \mathrm{ml})$ was added to the drinking water weekly for 8 weeks. The mice were followed for development of tumors or sacrificed after 15 weeks then bone marrow was isolated for establishment of Long Term Bone Marrow Cultures [28]. The original studies, Park, et al. [14] showed that 3 conditions were required for oral cavity cancer development in K14E7 Fancd2 ${ }^{--}$mice: 1) the absence of Fancd2; 2) the E7 oncogene; and 3) exposure to the 4-NQO carcinogen.

\section{Cell lines}

Bone marrow stromal cell lines and Interleukin-3 dependent cell lines from Fancd $2^{-/-}(129 / \mathrm{Sv})$ [10], Fancd $2^{-/-}(\mathrm{C} 57 \mathrm{BL} / 6)$ [9], and control mouse strains have been reported. The mouse HPV-induced cytokeratin 14 positive squamous cell tumor cell (CaSki) line was obtained from American Type Culture Collection (Manassas, VA). A clonal 3LL mouse (C57BL/6) Lewis Lung Carcinoma cell line [67] and a C57BL/6J control mouse spontaneous colon cancer were explanted to culture, and cell lines were established by us.

\section{Long-term bone marrow cultures}

Long-term bone marrow cultures (LTBMC) were established from the femur and tibia marrow of (129/ $\mathrm{Sv}$ background) Fancd $2^{+/+}$, Fancd $2^{+/}$, and $(\mathrm{FVB} / \mathrm{n}$ background) K14E7Fancd2 $2^{-/-}$mice according to published methods [9]. Briefly, the contents of a femur and tibia were flushed into McCoy's 5A medium (Gibco, Gaithersburg, MD) supplemented with 25\% horse serum (Cambrex, Rockland, ME), and $10^{-5} \mathrm{M}$ hydrocortisone sodium hemisuccinate. Cultures were incubated at $33^{\circ} \mathrm{C}$ in $7 \%$ $\mathrm{CO}_{2}$. After 4 weeks, the horse serum was replaced with 25\% FBS (Gibco, Gaithersburg, MD) [9]. The cultures were observed weekly for hematopoietic cell production and cobblestone island formation. Cobblestone islands of greater than or equal to 50 cells were scored weekly in each flask [9]. A two-sided two-sample $t$-test was used to compare the number of cobblestone islands between each genotype cultures each week. $P$-values less than 0.05 were regarded as significant.

\section{Hematopoietic cell colony-forming assays}

Aliquot of $5 \times 10^{4}$ fresh bone marrow cells or nonadherent cells removed at week 4 from each genotype 
long-term marrow culture were plated in triplicate in semisolid medium consisting of methylcellulose in IMDM, using a GelCount colony counter (Oxford Optronix, Oxford, UK) and maintained in a high humidity incubator according to published methods and using growth factor supplements as described [9]. Briefly, cells from fresh marrow or primary or subclonal IL-3-dependent cell lines were plated in $0.8 \%$ methylcellulose supplemented with 10\% Iscove's Modified Dulbecco's Medium (IMDM), $30 \%$ fetal bovine serum (FBS), $1 \%$ bovine serum albumin, 2 ng/mL IL-3 (Stemcell Technologies, Vancouver, Canada) at variable cell densities. At day 14, individual colonies were harvested and each cultured in a well of a 96 well plate in $0.2 \mathrm{~mL}$ of IMDM supplemented with $30 \%$ FBS and $1 \mathrm{ng} / \mathrm{mL}$ of Interleukin-3 (IL-3). Colonies of greater than 50 cells were scored on day 7 . Data were analyzed with single-hit multitarget models according to published methods [9].

\section{Establishment of IL-3-dependent hematopoietic progenitor cell lines and clonal cell sub-lines}

Non-adherent cells were harvested from each genotype mouse LTBMC at week 4 and cultured in sixwell tissue culture plates in Iscove's Modified Eagles Medium (IMDM) supplemented with $20 \%$ fetal calf serum (FBS) and $1.0 \mathrm{ng} / \mathrm{mL}$ recombinant mouse IL-3 (Peprotech, Rocky Hill, NJ). The cell lines were passaged weekly for 12-14 weeks to establish primary IL-3-dependent cell lines using published methods [9].

Clonal cell sub-lines were established from each of the genotype parent cell lines by expansion of single cell derived colonies. Cells were then replated in methylcellulose, colonies selected at 14 days, and cultured as above, to establish subclonal lines [9]. Confirmation of genotype after repeated subcloning was carried out for each cell line.

\section{Establishment of bone marrow stromal cell Lines and clonal cell sub-lines}

Adherent cell layers from one 4-week old LTBMC from each genotype mice were trypsinized and expanded by passage into Dulbecco's Modified Eagle's Medium $(\mathrm{DMEM})+10 \%$ FBS to establish bone marrow stromal cell lines according to published methods [9]. Cells were passaged for 10 weeks to establish cell lines. Cultures were incubated at $37^{\circ} \mathrm{C}$ in $5 \% \mathrm{CO}_{2}$.

\section{Flow cytometry analysis for cell surface phenotype}

Flow Analysis for CD3c, CD5, CD8, B220, GR1-Ter119, CD41, CD45, CD48, SCA-1, C-KIT, CD150, vimentin, adiponectin, collagen III, collagen IV, osteopontin, and osteocalcin (antibodies were obtained from Abcam Inc., Cambridge, MA or Santa Cruz Biotechnology, Inc., Santa Cruz, CA) were carried out according to the methods section sorting 10,000 cells in triplicate experiments. Briefly, bone marrow stromal cells and IL-3 dependent hematopoietic cells from K14E7 Fancd $2^{-/-}$and SV129 Fancd2 $2^{-/}$cells were prepared into single cell suspension and incubated with each FITC or PE conjugated antibody listed above at concentrations recommended by the manufacturer for one hour on ice. The cells were washed three times with phosphate buffered saline (PBS) and analyzed for positive cells by flow cytometry.

\section{Western blot for proteins}

Cell lines were cultured in DMEM medium (Lonza Cat. \#: 12-604F) with 10\% Fetal Bovine serum (Gemini Cat.\#: 100-500), 1\% L-Glutamine (Lonza Cat. \#: 17-605E) and 1\% Antibiotics Antimycotic Solution (Corning Cat. \#: 30-004-Cl). Total cellular protein was extracted using protein extraction buffer (IP Lysis Buffer, Thermo Scientific prod \#: 87787), containing protease inhibitor and phosphatase inhibitor cocktails (Thermo Scientific prod \#: 78442). Mouse tongue and skin tissue were freshly taken and chopped to fine pieces and homogenized in protein extraction buffer (same as cell protein extraction buffer). Protein concentration was determined using the Bio-Rad protein assay system (Bio-Rad Laboratories, Cat. \#: 500-0006). The proteins (15 $\mu \mathrm{g}$ per lane) were separated on denaturing polyacrylamide gels (Bio-Rad Laboratories, Mini-Protean TGX Gels Cat. \#: 456-1083) and then transferred to PVDF membranes (Bio-Rad Laboratories, Immun-Blot PVDF Cat. \#: 162-0177) by electrophoresis. Blots were blocked with 5\% Fat-free Dry Milk in TBST for $1 \mathrm{~h}$ and then incubated overnight with primary antibodies (see antibody table). The membranes were washed with TBST and processed with corresponding horseradish peroxidase-conjugated secondary antibodies (see antibody table). The proteins were exposed to x-ray film (5 to 30 seconds) using ECL detection reagent (Thermo Scientific SuperSignal West Dura Extended Duration Substrate Prod \#: 34075). To ensure equal protein loading, the same blot was subsequently developed for GAPDH expression.

$\mathrm{K} 6, \mathrm{~K} 16$, and $\mathrm{K} 17$ are found in oral mucosa and stratified epidermis of skin [27]. K17 has been reported to be found in normal skin and in malignant squamous cell lesions [27]. CK13 is expressed in normal epithelium, and is reduced after malignant transformation [27]. K10 is an early differentiation marker, found in the suprabasal epidermal layer in uninvolved skin with reduced expression in malignant lesion areas [27].

\section{Immunohistochemistry}

We used control anti-CK-13 antibody (ab92551) and anti-CK14 (ab7800) antibody for staining squamous cell 
specific Cytokeratins. For Kappa and Lambda staining, goat anti-Lambda light chain (Bethyl, Inc. A90-121A) and goat anti-kappa light chain (Bethyl, Inc. A90-119A), K14E7 Fanconi $\mathrm{d} 2^{--}$cells were seeded and grown in chamber slides and fixed with $100 \%$ methanol (5 min), permeabilized with $0.2 \%$ Triton $\mathrm{X}-100$ for 10 minutes and blocked with $1 \% \mathrm{BSA} / 22.5 \mathrm{mg} / \mathrm{ml}$ glycine in $0.1 \% \mathrm{PBS}$-Tween for 30 minutes. The cells were then incubated overnight at $+4^{\circ} \mathrm{C}$ with the antibody (ab92551) or (ab7800) at a 1/100 dilution, then incubated with secondary antibody (Dnk anti-rabbit alexa flour 488 or Dnk anti-goat alexa flour 488) for 1 hour at a 1/500 dilution (shown in green). Nuclear DNA was labeled with DAPI (shown in blue). Images were obtained using a Nikon Eclipse E800 microscope.

\section{Immunofluorescence}

Tumors were fixed using 10\% paraformaldehyde, embedded in paraffin, sectioned, and deparaffinized in xylene for 10 min twice and rehydrated in $100 \%, 95 \%$, and $70 \%$ ethanol for $5 \mathrm{~min}$. Antigens were unmasked by boiling for $12 \mathrm{~min}$ in $1 \mathrm{mM}$ EDTA. Sections were blocked with $3 \% \mathrm{H} 2 \mathrm{O} 2$ at room temperature for $30 \mathrm{~min}$, washed in PBS for $5 \mathrm{~min} \times 3$, incubating in $10 \% \mathrm{BSA}$ at room temperature for $15 \mathrm{~min}$. The sections were incubated with the primary antibody at $4^{\circ} \mathrm{C}$ overnight, and washed in PBS water for $5 \mathrm{~min}$. Hematoxylin was added for one followed by Methylene Blue Reagent Solution for $1 \mathrm{~min}$. The sections were dehydrated in $70 \%, 95 \%$, and $100 \%$ ethanol followed by xylene for $5 \mathrm{~min}$. the slides were mounted and analyzed.

\section{Clonogenic irradiation survival curves for K14E7 Fancd2 ${ }^{-/-}$mouse IL-3-dependent cell lines or freshly removed whole bone marrow}

IL-3-dependent non-adherent cells or whole bone marrow from each genotype mice were irradiated in suspension culture to doses between 0 and 8 Gy as described above. Cells were plated in triplicate in methylcellulose medium containing recombinant mouse stem cell factor (SCF), IL-3, IL-6, and recombinant human erythropoietin (EPO) (Stem Cell Technologies, Vancouver, BC). CFU-GM were scored on day 7-9 for the IL-3-dependent cell lines and CFU-GM, BFU-E, and CFU-GEMM were scored between days 10 and 13 for the whole bone marrow. In some experiments, colonies growing in plates containing cells irradiated to 6 Gy or 8 Gy were removed and expanded. Data were analyzed with singlehit multitarget models according to published methods [9].

In other experiments with fresh marrow, cells were plated in semisolid medium with Fetal Bovine Serum

List of premium antibodies used for western immunoblotting studies

\begin{tabular}{|l|l|l|l|}
\hline Antibodies & Dilution & Source & Catalogue Numbers \\
\hline Mouse anti CK-5 & $1: 1000$ & Abcam & ab128190 \\
\hline Rabbit anti CK-6 & $1: 1000$ & Abcam & ab52869 \\
\hline Rabbit anti CK-10 & $1: 500$ & Abcam & ab76318 \\
\hline Rabbit anti CK-13 & $1: 1000$ & Abcam & ab92551 \\
\hline Mouse anti CK-14 & $1: 1000$ & Abcam & ab7800 \\
\hline Rabbit anti CK-16 & $1: 1000$ & Abcam & ab182791 \\
\hline Rabbit anti CK-17 & $1: 500$ & Abcam & ab109725 \\
\hline Mouse anti GAPDH & $1: 2000$ & Millipore & MAB374 \\
\hline Mouse anti HPV E7 & $1: 500$ & Santa Cruz & Sc-6981 \\
\hline
\end{tabular}

List of secondary antibodies used for western immunoblotting studies

\begin{tabular}{|ll|l|l|l|}
\hline Secondary Antibodies & Dilution & Source & Catalogue Number \\
\hline $\begin{array}{l}\text { Anti-Rabbit IgG, HRP } \\
\text { Conjugate }\end{array}$ & $1: 15000$ & Promega & W401B \\
\hline $\begin{array}{l}\text { Anti-Mouse IgG, HRP } \\
\text { Conjugate }\end{array}$ & $1: 15000$ & Promega & W402B \\
\hline
\end{tabular}

for $5 \mathrm{~min} \times 3$. Secondary antibody was added for $1 \mathrm{hr}$ at room temperature and washed in PBS for $5 \mathrm{~min} \times 3$. The sections were incubated in Elite ABC Kit (Vector \#PK6100 ) at room temperature for $30 \mathrm{~min}$, washed in PBS for $5 \mathrm{~min} \times 3$, incubated in DAB kit (Vector \#SK-4100) at room temperature for $1 \mathrm{~min}$, and washed in running
(FBS), 10\% Bovine Serum Albumin (BSA), recombinant mouse IL-3, also containing L-glutamine, $3 \mathrm{U} / \mathrm{mL}$ erythropoietin, and 2-mercaptoethanol. Fresh marrow colonies were scored at day 7 and 14 and subdivided as colony forming unit granulocyte macrophage (CFU-GM), Burst Forming Unit Erythroid (BFUe), and (CFU-GEMM) 
granulocyte-erythroid-megakaryocyte-macrophage. Colony forming unit granulocyte-macrophage (CFU-GM) burst forming erythroid (BFUe) and (CFU-GEMM) of 50 cells or greater were counted on both days 7 and 14 after plating. A two-sided, two-sample $t$-test was used as described above [9].

\section{Clonogenic irradiation survival curves for K14E7Fancd2 ${ }^{-/}$mouse bone marrow stromal cell lines}

Bone marrow stromal cell lines generated from the trypsinized and repassaged LTBMC adherent layer at week 4 [9] from each genotype mouse strain were subcloned in single cell counting wells of micro-well plates as described [9]. Clonal cell lines were expanded. Cells were then trypsinized and irradiated in suspension culture to doses between 0 and 8 Gy at $70 \mathrm{cGy} / \mathrm{min}$ using a Shepherd Mark $1{ }^{137} \mathrm{Cs}$ y-ray source (J.L. Shepherd, San Fernando, CA, USA). Cells were plated in quadruplicate in Linbro plates (Fisher Scientific, Pittsburgh, PA, USA) and incubated at $37^{\circ} \mathrm{C}$ and $5 \% \mathrm{CO}_{2}$ for $9-11$ days, stained with crystal violet, and colonies of $>50$ cells were counted.

\section{E6/E7 plasmid transfection of stromal and IL-3 dependent hematopoietic progenitor cell lines}

IL-3 dependent nonadherent cell lines derived from each genotype LTBMC or clonal stromal cell lines were transfected with the PLXSN16E6E7 plasmid containing both E6 and E7; PLXSN16E7 (Addgene, Inc., Cambridge, MA) according to the manufacturer's directions. Selection of G418 resistant clones was carried out with transfected and control IL-3 dependent hematopoietic cell lines including cell lines: 32D cl3 [29], as well as cell lines derived from Fancd $2^{+/}(129 / \mathrm{Sv})[10]$, Fancd $2^{-/}(129 / \mathrm{Sv})$ [10], and cell lines derived from control $129 / \mathrm{Sv}, \mathrm{FVB} / \mathrm{n}$, and (129/Sv X FVB/n)-F1 long-term marrow cultures.

\section{Cytokeratin and E7 HPV oncogene expression in cell lines and fresh tissues}

Protein was extracted from fresh tissues or cell lines from each mouse strain including: 129/Sv Fancd $2^{+++}, 129 /$ Sv Fancd2 ${ }^{-/}$, K14E7 Fancd2 ${ }^{+/+}$, and K14E7 Fancd2 ${ }^{-/-}$ mice. We first studied bone marrow stromal cell lines and IL-3 dependent cell lines as well as freshly removed fresh tissue from K14E7 Fancd2 ${ }^{+/+}$and K14E7 Fancd2 $2^{-/-}$mice. Protein was extracted using protein extraction buffer (IP Lysis Buffer, Thermo Scientific prod \#: 87787), containing protease inhibitor and phosphatase inhibitor cocktails (Thermo Scientific prod \#: 78442). Protein concentration was determined using the Bio-Rad protein assay system (Bio-Rad Laboratories, Cat. \#: 500-0006). The proteins (15 $\mu \mathrm{g}$ per lane) were separated on denaturing polyacrylamide gels (Bio-Rad Laboratories, Mini-Protean
TGX Gels Cat. \#: 456-1083), and then transferred to PVDF membranes (Bio-Rad Laboratories, Immun-Blot PVDF Cat. \#: 162-0177) by electrophoresis. Blots were blocked with 5\% Fat-free Dry Milk in TBST for $1 \mathrm{~h}$ and then incubated overnight with primary antibodies to mouse anti-CK14 (ab7800 Abcam, Cambridge, MA), or mouse anti-HPV E7 protein (SC6981, Santa Cruz Biotechnology, Santa Cruz, CA). The membranes were then washed with TBST and processed with a corresponding horseradish peroxidase-conjugated secondary antibodies (HRP anti mouse IgG, Promega, Madison, WI). The blotted proteins were then exposed to $\mathrm{x}$-ray film (5 to 30 seconds) using ECL detection reagent (Thermo Scientific SuperSignal West Dura Extended Duration Substrate Prod. \#: 34075). To ensure equal protein loading, each blot was also subsequently developed for level of GAPDH (glyceraldehyde-3-phosphate-dehydrogenase) expression.

\section{Tumor formation assays}

To demonstrate that K14E7 Fancd2 $2^{-/-}$clonal cell lines were tumorigenic, $1 \times 10^{6}$ cells from K14E7 Fancd2 $2^{-/-}$clone 1 or K14E7 Fancd2 ${ }^{+/+}$clone 5 cell lines were injected subcutaneously in the flank of each of 5 (FVB X 129/Sv) F1 mice. Other groups of 5 mice received I.V. injection of the same cell numbers. Mice were followed for the development of tumors at which time they were sacrificed, tumors removed, fixed in $10 \%$ paraformaldehyde, sectioned, and then sections were stained with hematoxylin and eosin or antibodies to kappa and lambda light chains (A90-121A or A90-119A, Bethyl Laboratories, Montgomery, TX).

\section{Detection of E7 oncogene protein with nuclear p53 and $R b$}

The primary antibodies used for co-localization studies included: a rabbit polyclonal antibody to p53 (Santa Cruz Biotechnology, Santa Cruz, CA, sc6243); a rabbit polyclonal antibody to $\mathrm{Rb}$ (Santa Cruz Biotechnology, Santa Cruz, CA, sc-50); and a mouse monoclonal antibody to E7 (Santa Cruz Biotechnology, Santa Cruz, CA, sc-65711). Secondary antibodies used included: donkey anti-mouse 488 and donkey anti-rabbit 568 (obtained from Invitrogen, Waltham, MA). DAPI was used as a nuclear fluorescent stain that binds strongly to A-T rich regions in DNA. Confocal images were obtained with an Olympus Fluoview 100 confocal microscope and companion software FV10-ASW1.6. Images were acquired at a resolution of $1024 \times 1024$ pixels.

\section{Statistical methods}

The in vitro radiation survival curves were analyzed with the single-hit multi-target model, and were compared using $\mathrm{D}_{0}$ (final slope representing multiple-event killing) 
and $\tilde{\mathrm{n}}$ (extrapolation number measuring width of the shoulder on the radiation survival curve) [9]. Results for $\mathrm{D}_{0}$ and $\tilde{\mathrm{n}}$ were presented as the mean \pm standard error (SEM) from multiple measurements and compared with the two-sided two-sample $t$-test.

For the LTBMC data, weekly cobblestone island numbers; non-adherent cell numbers $\left(\times 10^{6}\right)$ per flask; percent confluence of adherent cells; day 7 colony forming progenitor cells; and day 14 colony forming cells were counted as described [9] and compared at each week between any two of the four groups (i.e., K14E7 Fancd2 ${ }^{+/+}$, K14E7 Fancd2 ${ }^{-/-}$, control $(129 / \mathrm{Sv} \times \mathrm{FVB}) \mathrm{F}_{1}$ and Fancd 2 ${ }^{-/}(129 / \mathrm{Sv})$. Data were summarized as mean \pm standard deviation, and $p$-values were calculated with the two-sided two-sample $t$-test.

For Western blots data were analyzed by densitometry and summarized with mean \pm standard deviation in each group. $P$-values for the comparison between any two groups were calculated with the twosided two-sample $t$-test.

For the other continuous endpoints, comparisons were also performed using a $t$-test if they were normally distributed, or with Wilcoxon rank sum test otherwise. In all these tests, a $p$-value of less than 0.05 was regarded as significant. As an exploratory analysis, we did not adjust $p$-values for multiple comparisons.

\section{ACKNOWLEDGMENTS}

The authors thank Bevin Engelward, Ph.D., Alan D'Andrea, M.D., and Paul Lambert, Ph.D. for helpful discussions and review of the data.

\section{CONFLICTS OF INTEREST}

Drs. Greenberger and Epperly have a conflict of interest due to the issuance of patents for JP4-039 and related compounds as radiation protectors and mitigators.

\section{GRANT SUPPORT}

Supported by: NIAID/NIH grant U19-A10680201, the Fanconi Anemia Research Foundation, and the UPCI Animal Facility, which is supported in part by $\mathrm{NIH}$ P30CA047904.

\section{REFERENCES}

1. Soulier J. Fanconi Anemia. Hematology American Society. 2011; 2011:492-497.

2. Sareen A, Chaudhury I, Adams N, Sobeck A. Fanconi anemia proteins FANCD2 and FANCI exhibit different DNA damage responses during S-phase. Nucleic Acids Res. 2012; 40:8425-8439.

3. Garcia-Higuera I, Tangiguchi T, Ganesan S, Meyn MS, Timmers C, Hejna J, Grompe M., D’Andrea AD. Interaction of the Fanconi anemia proteins and BRCA1 in a common pathway. Molecular Cell. 2001; 7:249-262.

4. Lachaud C, Moreno A, Marchesi F, Toth R, Blow JJ, Rouse J. Ubiquitinated Fancd 2 recruits Fan1 to stalled replication forks to prevent genome instability. Science. 2016; 351:846-849.

5. Hoskins EE, Morris TA, Higginbotham JM, Spardy N, Cha E, Kelly P, Williams DA, Wikenheiser-Brokamp KA, Duensing S, Wells SI. Fanconi anemia deficiency stimulates HPV-associated hyperplastic growth in organotypic epithelial raft culture. Oncogene 2009; 28:674-685.

6. Kutler DI, Auerbach AD, Satagopan J, Giampietro PF, Batish SD, Huvos AG, Goberdhan A, Shah JP, Singh B. High incidence of head and neck squamous cell carcinoma in patients with Fanconi anemia. Arch Otolaryngology Head and Neck Surgery. 2003; 129:106-112.

7. Parmar K, Kim J, Sykes SM, Shimamura A, Stuckert P, Zhu K, Hamilton A, Deloach MK, Kutok JL, Akashi K, Gilliland DG, D'Andrea A. Hematopoietic stem cell defects in mice with deficiency of Fancd 2 or Usp1. Stem Cells. 2010; 28:1186-1195.

8. Shinde A, Berhane H, Rhieu BH, Kalash R, Xu K, Goff J, Epperly MW, Franicola D, Zhang X, Dixon T, Shields D, Wang H, Wipf P. et al. Intraoral mitochondrial-targeted GSNitroxide, JP4-039, radioprotects normal tissue in tumorbearing radiosensitive Fancd $2^{-/-}(\mathrm{C} 57 \mathrm{BL} / 6)$ mice. Radiat Res. 2016; 185:134-150.

9. Berhane H, Epperly MW, Goff J, Kalash R, Cao S, Franicola D, Zhang X, Shields D, Houghton F, Wang H, Sprachman M, Wipf P, Li S, et al. Radiobiologic differences between bone marrow stromal and hematopoietic progenitor cell lines from Fanconi Anemia $\left(\right.$ Fancd $^{-/-}$) mice. Radiat Res. 2014; 181:76-89.

10. Berhane H, Shinde A, Kalash R, Xu K, Epperly MW, Goff J, Franicola D, Zhang X, Dixon T, Shields D, Wang H, Wipf P, Li S, et al. Amelioration of irradiation induced oral cavity mucositis and distant bone marrow suppression in Fancd $2^{-/-}$mice by intraoral JP4-039/F15. Radiat Res. 2014; 182:35-49.

11. Moody CA, Laimins LA. Human papillomavirus oncoproteins: pathways to transformation. Nature Reviews Cancer. 2010; 10:550-560.

12. Ghittoni R, Accardi R, Chiocca S, Tommasino $\mathrm{M}$. Role of human papillomaviruses in carcinogenesis. Ecancermedicalscience. 2015; 9:526.

13. Katz J, Islam MN, Bhattacharyya I, Sandow P, Moreb JS. Oral squamous cell carcinoma positive for $\mathrm{p} 16 /$ human papilloma virus in post allogeneic stem cell transplantation: 2 cases and review of the literature. Med Oral Pathol Oral Radiol. 2014; 118:e74-e78.

14. Park JW, Shin M-K, Lambert PF. High incidence of female reproductive tract cancers in FA-deficient HPV16transgenic mice correlates with E7's induction of DNA damage response, an activity mediated by E7's inactivation of pocket proteins. Oncogene 2014; 33:3383-3391. 
15. Boulet G, Horvath C, Broeck DV, Sahebali S, Bogers J. Human papillomavirus: E6 and E7 oncogenes. Int J Biochem \& Cell Biol. 2007; 39:2006-2011.

16. Stone SC, Rossetti RAM, Lima AM, Lepique AP. HPV associated tumor cells control tumor microenvironment and leukocytosis in experimental models. Immunity, Inflammation, and Disease 2014; 2:63-75.

17. Kimple RJ, Smith MA, Blitzer GC, Torres AD, Martin JA, Yang RZ, Peet CR, Lorenz LD, Nickel KP, Klingelhutz AJ, Lambert PF, Harani PM. Enhanced radiosensitivity in HPVpositive head and neck cancer. Cancer Research. 2013; 73: 4791-4800.

18. Herbert R, Liem A, Pitot, H, Lambert PF. Squamous epithelial hyperplasia and carcinoma in mice transgenic for the human papillomavirus type $16 \mathrm{E} 7$ oncogene. J of Virology. 1996; 70:1873-1881.

19. Wong WM, Parvathaneni U, Jewell PD, Martins RG, Futran ND, Laramore GE, Liao JJ. Squamous cell carcinoma of the oral tongue in a patient with Fanconi anemia treated with radiotherapy and concurrent cetuximab: A case report and review of the literature. Head and Neck. 2013; 35:E292-E298.

20. Rosenberg PS, Socie G, Alter BP, Gluckman E. Risk of head and neck squamous cell cancer and death in patients with Fanconi anemia who did and did not receive transplants. Blood. 2005; 105:67-73.

21. Chlon TM, Hoskins EE, Mayhew CN, WikenheiserBrokamp KA, Davies SM, Mehta P, Myers KC, Wells JM, Wells SI. High-risk human papillomavirus E6 protein promotes reprogramming of Fanconi Anemia patient cells through repression of $\mathrm{p} 53$ but does not allow for sustained growth of induced pluripotent stem cells. J Virol. 2014; 88:11315-11325.

22. Liu GB, Chen J, Wu ZH, Zhao K-N. Association of human papillomavirus with Fanconi anemia promotes carcinogenesis in Fanconi anemia patients. Reviews in Medical Virology 2015; 17 (Epub ahead of print).

23. Chappell WH, Gautam D, OK ST, Johnson BA, Anacker DC, Moody CA. Homologous recombination repair factors Rad51 and BRCA1 are necessary for productive replication of human papillomavirus 31. J Virology 2016; 90:2639-2647.

24. Murvai M, Borbely AA, Konya J, Gergely L, Veress G. Effect of human papillomavirus type 16 E6 and E7 oncogenes on the activity of the transforming growth factor- $\beta 2$ (TGF- $\beta 2$ ) promoter. Arch Virol. 2004; 149:2379-2392.

25. Zhang H, Kozono DE, O'Connor KW, Vidal-Cardenas S, Rousseau A, Hamilton A, Moreau L, Gaudiano EF, Greenberger J, Bagby G, Soulier J, Grompe M, Parmar K, et al. TGF- $\beta$ inhibition rescues hematopoietic stem cell defects and bone marrow failure in Fanconi Anemia. Cell Stem Cell. 2016; 18:1-14.

26. Park JW, Pitot HC, Strati K, Spardy N, Duensing S, Grompe M, Lambert PF. Deficiencies in the Fanconi Anemia DNA damage response pathway increase sensitivity to HPV-associated head and neck cancer. Cancer Res. 2010; 70:9959-9968.

27. Tolvola DM, Boor P, Alam C, Stmad P. Keratins in health and disease. Current Opinion in Cell Biology. 2015; 32:73-81.

28. Sakakeeny MA, Greenberger JS. Granulopoiesis longevity in continuous bone marrow cultures and factor dependent cell line generation: Significant variation among 28 inbred mouse strains and outbred stocks. J Nat Cancer Inst. 1982; 68:305-317.

29. Greenberger JS, Sakakeeny MA, Humphries KC, Eaves CG, Eckner RJ. Demonstration of permanent factordependent multipotential (erythroid/neutrophil/basophil) hematopoietic progenitor cell lines. Proc Natl Acad of Sciences, USA. 1983; 80:2931-2935.

30. Ohta M, Anklesaria P, Wheaton M, Ohara A, Pierce JH, Holland CA, Greenberger JS. Retroviral src gene expression in continuous marrow culture increases the self-renewal capacity of multilineage hematopoietic stem cells. Leuk. 1989; 3:206-226.

31. Greenberger JS. Phenotypically distant target cells for murine sarcoma and leukemia virus marrow transformation in vitro. J Nat Cancer Inst. 1979; 62:337-348.

32. Greenberger JS, Shadduck RR, Jaenisch R, Waheed A, Sakakeeny MA. Effects of infection in vitro or germ line integration of Moloney murine leukemia virus on hematopoiesis in long-term bone marrow culture. Cancer Res. 1981; 41:3556-3565.

33. Greenberger JS, Eckner RJ, Sakakeeny M, Cohen G. Role of stromal and hematopoietic stem cells in Friend spleen focus forming virus effects in continuous bone marrow culture. Leukemia Res. 1983; 7:621-636.

34. Greenberger JS, Daugherty C, Sakakeeny MA, Braun J, Pierce J, Eckner J, FitzGerald TJ. Friend virus-infected long-term bone marrow cultures produce colony stimulating factor-dependent and independent granulocyte-macrophage progenitor cells for over four years in vitro. Leukemia Res. 1987; 11:51-61.

35. Greenberger JS, Otten JA, Eckner RJ, Tennant RW. In vitro quantitation of lethal and leukemogenic effects of gamma irradiation on stromal and hematopoietic stem cells in continuous mouse bone marrow culture. Int J Radiat Oncol Biol Phys. 1982; 8:1155-1165.

36. Greenberger JS, Palaszynski EW, Pierce JH, Sakakeeny MA, Ruscetti SK, Ihle JM, Daugherty C, Aaronson SA. Biologic effects of prolonged L-Phenylalanine mustard treatment of murine long-term bone marrow cultures and IL-3 dependent hematopoietic progenitor cell lines. J Nat Cancer Inst. 1985; 74:247-262.

37. Greenberger JS, Newburger PE, Sakakeeny MA. Phorbol myristate acetate stimulates macrophage proliferation and differentiation and alters granulopoiesis and leukemogenesis in long-term bone marrow cultures. Blood. 1980; 56:368-379.

38. Payne DA, Chan T-S, Schoaib BO, Patten BM, Tyring SK. Human papillomavirus is associated with monoclonal 
gammopathies of unknown significance. J Biomed Sci. 1996; 3:319-322.

39. Payne D, Tyring S, Kumar S, Patten B, Shoaib B, Chan T. Human papillomaviruses (HPV) are associated with multiple myeloma. Int J Oncol. 1996; 9:345-349.

40. Payne DA, Chan TS, Patten B, Tyring SK. Extrachromosomal human papillomavirus (HPV) in multiple myeloma and monoclonal gammopathy of unknown significance (MGUS) patients. Anticancer Res. $1995 ; 15: 2213-2215$.

41. Akimov SS, Ramezani A, Hawley TS, Hawley RG. Bypass of senescence, immortalization, and transformation of human hematopoietic progenitor cells. Stem Cells 2005; 23:1423-1433.

42. Malcolm KM, Gill J, Leggatt GR, Boyd R, Lambert P, Frazer IH. Expression of the HPV16E7 oncoprotein by thymic epithelium is accompanied by disrupted $\mathrm{T}$ cell maturation and a failure of the thymus to involute with age. Clin Devel Immuno. 2003; 10:91-103.

43. Roecklein BA, Torok-Storb B. Functionally distinct human marrow stromal cell lines immortalized by transduction with the human papilloma virus E6/E7 genes. Blood. 1995; 85:997-1005.

44. Worku M, Fersht N, Martindale C, Funes JM, Short SC. Sequential transformation of mesenchymal stem cells is associated with increased radiosensitivity and reduced DNA repair capacity. Radiat Res. 2013; 179:698-706.

45. Hung SC, Yang DM, Chang CF, Lin RJ, Wang JS, LowTone HL, Yang WK. Immortalization without neoplastic transformation of human mesenchymal stem cells by transduction with HPV16 E6/E7 genes. Int J Cancer. 2004; 110:313-319.

46. Theodore S, Sharp S, Zhou J, Turner T, Li H, Miki J, Ji Y, Patel V, Yates C, Rhim JS. Establishment and characterization of a pair of non-malignant and malignant tumor derived cell lines from an African American prostate cancer patient. Int J Oncol. 2010; 37:1477-1482.

47. Hussain I, Fathallah I, Accardi R, Yue J, Saidj D, Shukla R, Hasan U, Gheit T, Niu Y, Tommasino M, Sylla BS. NF-kB protects human papillomavirus type $38 \mathrm{E} 6 / \mathrm{E} 7$-immortalized human keratinocytes against tumor necrosis factor alpha and UV-mediated apoptosis. J Virol. 2011; 85:9013-9022.

48. Li J, Gao HQ, Zhao CL, Li LZ, Ji CY, Hou M, Plebaski M. Dendritic cells present particulate E7 protein of human papillomavirus and induce strong immunity. [Article in Chinese]. Zhonghua Yi Xue Za Zhi, 2004; 84:932-936.

49. DeFabritiis P, Bregni M, Lipton J, Greenberger J, Nadler L, Rothstein L, Korbling M, Ritz J, Bast RC Jr. Elimination of clonogenic Burkett's lymphoma cells from human bone marrow using 4 hydroperoxycyclophosphamide (4-HC) in combination with monoclonal antibodies and complement. Blood 1985; 65:1064-1070.

50. Greenberg HM, Parker LM, Newburger PE, Said J, Cohen GI, Greenberger JS. Corticosteroid dependence of continuous hematopoiesis in vitro with murine or human bone marrow. In: Neth R, Gallo RC, Ed. Modern Trends in Human Leukemia IV. Berlin: Springer Verlag; 1981. P. 289-293.

51. Greenberger JS, Hoffman N, Lieberman M, Botnick LE, Sakakeeny MA, Eckner RJ. Pool size of pluripotential hematopoietic stem cells increased in continuous bone marrow culture by Friend spleen focus forming virus. Journal of National Cancer Institute 1983; 70:323-331.

52. Liu Y, Zhang Y, Han W. Triphenotypic multiple myeloma expressing kappa or lambda light chain, or both. Br J Haematol. 2013; 160:4.

53. Stoppler H, Stoppler MC, Johnson E, SimbulanRosenthal CM, Smulson ME, Lyer S, Rosenthal DS, Schlegel R. The E7 protein of human papillomavirus type 16 sensitizes primary human keratinocytes to apoptosis. Oncogene 1998; 17:1207-1214.

54. Massimi P, Banks L. Repression of p53 transcriptional activity by the HPV E7 proteins. Virology. 1997; 227:255-259.

55. Song S, Gulliver GA, Lambert PF. Human papillomavirus type $16 \mathrm{E} 6$ and E7 oncogenes abrogate radiation-induced DNA damage responses in vivo through p53-dependent and p53-independent pathways. Proc Natl Acad Sci USA. 1998; 95:2290-2295.

56. Demers GW, Halbert CL, Galloway DA. Elevated wildtype p53 protein levels in human epithelial cell lines immortalized by the human papillomavirus type 16 E7 gene. Virology. 1994; 198:169-174.

57. Fogel S, Riou G. The early HPV16 proteins can regulate mRNA levels of cell cycle genes in human cervical carcinoma cells by p53-independent mechanisms. Virology. 1998; 244:97-107.

58. Butz K, Whitaker N, Denk C, Ullmann A, Geisen C, HoppeSeyler F. Induction of the p53-target gene GADD45 in HPV-positive cancer cells. Oncogene. 1999; 18:2381-2386.

59. Inoue T, Oka K, Yong-11 H, Vousden KH, Kyo S, Jing P, Hakura A, Yutsudo M. Dispensability of p53 degradation for tumorigenicity and decreased serum requirement of human papillomavirus type 16 E6. Molecular Carcinogenesis. 1998; 21:215-222.

60. Shai A, Pitot HC, Lambert PF. P53 loss synergizes with estrogen and papillomaviral oncogenes to induce cervical and breast cancers. Cancer Res. 2008; 68:2622-2631.

61. Oh J-E, Kim J-O, Shin J-Y, Zhang XH, Won HS, Chun SH, Jung CK, Park WS, Nam SW, Eun JW, Kang JH. Molecular genetic characterization of p53 mutated oropharyngeal squamous cell carcinoma cells transformed with human papillomavirus E6 and E7 oncogenes. Int J Oncol. 2008; 68:2622-2631.

62. Aguilar-Lemarroy A, Gariglio P, Whitaker NJ, Eichhorst ST, zur Hausen H, Krammer PH, Rosl F. Restoration of p53 expression sensitizes human papillomavirus type 16 immortalized human keratinocytes to CD95-mediated apoptosis. Oncogene 2002; 21:165-175. 
63. Peacock JW, Benchimol S. Mutation of the endogenous p53 gene in cells transformed by HPV-16 E7 and EJ c-ras confers a growth advantage involving an autocrine mechanism. The EMBO Journal 1994; 13:1084-1092.

64. Jansma AL, Martinez-Yamout MA, Liao R, Sun P, Dyson HJ, Wright PE. The high-risk HPV16 E7 oncoprotein mediates interaction between the transcriptional coactivator CBP and the retinoblastoma protein pRb. J Mol Biol. 2014; 426:4030-4048.

65. Martinez-Zapien D, Ruiz FX, Poirson J, Mitschler A, Ramirez J, Forster A, Cousido-Siah A, Masson M, Vande Pol S, Podjarny A, Trave G, Zanier K. Structure of the E6/ E6AP/p53 complex required for HPV-mediated degradation of p53. Nature. 2016; 529:541.

66. Guo Y, Updegraff BL, Park S, Durakoglugil D, Cruz VH, Maddux S, Hwang TH, O'Donnell KA. Comprehensive ex vivo transposon mutagenesis identifies genes that promote growth factor independence and leukemogenesis. Cancer Res. 2015; 76:773-786.

67. Epperly MW, Defilippi S, Sikora C, Gretton J, Kalend K, Greenberger JS. Intratracheal injection of manganese superoxide dismutase (MnSOD) plasmid/liposomes protects normal lung, but not orthotopic tumors from irradiation. Gene Ther. 2000; 7:1011-1018.

68. Jiao W, Datta J, Lin H-M, Dundr M, Rane SG. Nucleocytoplasmic shuttling of the retinoblastoma tumor suppressor protein via Cdk phosphorylation-dependent nuclear export. J Biol Chemistry. 2006; 28:38098-38108.
69. Liu G, Xirodimas DP. NUB1 promotes cytoplasmic localization of p53 through cooperation of the NEDD8 and ubiquitin pathways. Oncogene. 2010; 29:2252-2261.

70. Prieto C, Stam RW, Agraz-Doblas A, Ballerini P, Camos M, Castano J, Marschalek R, Bursen A, Varela I, Bueno C, Menendez P. Activated KRAS cooperates with MLL-AF4 to promote extramedullary engraftment and migration of cord blood CD34+ HSPC but is insufficient to initiate leukemia. Cancer Res. 2016; 76:2478-2489.

71. FitzGerald TJ, Rothstein LA, Daugherty C, McKenna M, Kase K, Greenberger JS. The activated human n-ras oncogene enhances $\mathrm{x}$-irradiation repair of mammalian cells in vitro less effectively at low-dose-rate: Implications for increased therapeutic ratio of low-dose-rate irradiation. Am J Clin Oncol: Clinical Trials. 1985; 8:517-522.

72. Weichselbaum RR, Nove J, Little JB. Deficient recovery from potentially lethal radiation damage in ataxiatelangiectasia and xeroderma pigementosum. Nature. 1978; 271:261-262.

73. Bernard ME, Kim H, Berhane H, Epperly MW, Franicola D, Zhang X, Houghton F, Shields D, Wang H, Bakkenist CJ, Frantz MC, Wipf P, Greenberger JS. GS-nitroxide (JP4-039) mediated radioprotection of human Fanconi Anemia cell lines. Radiat Res. 2011; 176:603-612. 